\title{
Kelentingan Nafkah Rumah Tangga Pedagang Pasar Terapung di Banjarmasin : Kajian Gender dalam Sosiologi Nafkah
}

\section{Livelihood Resilience of Floating Market Traders in Banjarmasin : a Gender Lens of Livelihood Sociology}

\author{
Dhea Dasa Cendekia Zairin ${ }^{1, *}$, Arya Hadi Dharmawan, Bayu Eka Yulian
}

\author{
${ }^{1}$ Departemen Sains Komunikasi dan Pengembangan Masyarakat, Institut Pertanian Bogor, Bogor 16680, Indonesia. \\ ${ }^{*}$ E-mail korespondensi: dheadasa10@gmail.com
}

Received: March 6, 2021 | Revised: August 5, 2021 | Accepted: August 30, 2021| Online publication: September 8, 2021

\begin{abstract}
The floating market is a unique marketplace compared to other marketplaces, because the trading activities take place by boat on the river. The difference in boat sizes owned by men and women traders can indicate different socio-economic status of the traders. In order to improve the economic status, household members usually take up a number of additional activities to meet various needs. Various sources of income may be gained from trade and non-trade sectors. This research is a quantitative research supported by qualitative data. The data collection used questionnaires as a tool for gaining quantitative data and in-depth interviews for obtaining qualitative data. The purpose of this research is to analyze the structure of household income of the traders, the mechanism of adaptation to survive, and the factors that support the achievement of livelihood resilience of male and female floating market traders household. The results of this study indicate that female floating market traders are the important breadwinners in the household. In addition, with all the limitations, women traders' adaptability to achieve livelihood resilience is better than male traders. The ability to use their own resources is the key to achieving livelihood resilience for women traders of floating market.
\end{abstract}

Keywords : floating market, gender, household, livelihood resilience, traders

\section{ABSTRAK}

Pasar terapung memiliki keunikan tersendiri dibandingkan dengan pasar lainnya, karena aktivitas jual-beli berlangsung di atas sungai menggunakan perahu. Perbedaan ukuran perahu laki-laki dan perempuan pedagang pasar terapung dapat menunjukkan perbedaan status sosial-ekonomi. Demi meningkatkan keadaan ekonomi, anggota rumah tangga pedagang pasar terapung memanfaatkan modal nafkah yang dimiliki untuk memenuhi kebutuhan hidup. Berbagai sumber nafkah juga dimanfaatkan, baik dari sektor perdagangan maupun non-perdagangan. Penelitian ini merupakan penelitian kuantitatif yang didukung dengan data kualitatif. Teknik pengumpulan data yang digunakan melalui kuesioner untuk data kuantitatif dan wawancara mendalam untuk data kualitatif. Tujuan dari penelitian ini adalah untuk menganalisis perbandingan struktur nafkah, mekanisme adaptasi nafkah, dan faktorfaktor yang mendukung tercapainya kelentingan nafkah rumah tangga pedagang pasar terapung laki-laki dan perempuan. Hasil penelitian ini menunjukkan bahwa perempuan pedagang pasar terapung menjadi pencari nafkah utama dalam rumah tangga. Selain itu, dengan segala keterbatasan yang perempuan miliki, kemampuan adaptasi mereka untuk mencapai kelentingan nafkah lebih baik dibandingkan pedagang laki-laki. Kemampuan dalam memanfaatkan sumberdaya milik sendiri dengan sangat baik menjadi kunci tercapainya kelentingan nafkah rumah tangga perempuan pedagang pasar terapung.

Kata kunci: pasar terapung, gender, rumah tangga, kelentingan nafkah, pedagang

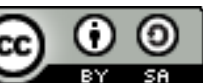

Content from this work may be used under the terms of the Creative Commons Attribution-Share A like 4.0 International. Any further distribution of this work must maintain attribution to the author(s) and the title of the work, journal citation and DOI.

Published under Department of Communication and Community Development Science, IPB University and in association with Ikatan Sosiologi Indonesia

E-ISSN: 2302-7525 | P-ISSN: 2302-7157 


\section{PENDAHULUAN}

Peran perempuan dalam pekerjaan sektor publik semakin meningkat. Perbaikan ketenagakerjaan seperti meningkatnya partisipasi kerja perempuan dan penurunan pengangguran selama satu dekade terakhir juga diikuti dengan peningkatan persentase perempuan yang bekerja sebagai tenaga profesional. Berdasarkan data dari Kementerian Pemberdayaan Perempuan dan Perlindungan Anak Republik Indonesia (2019) peningkatan IDG (Indeks Pemberdayaan Gender) tahun 2018 terjadi karena kenaikan dua komponen, yakni persentase perempuan sebagai tenaga profesional dan sumbangan pendapatan perempuan. Menurut Salaa (2015), ibu rumah tangga saat ini tidak hanya berperan di sektor domestik, melainkan juga di sektor publik seperti: berdagang keliling, berdagang kecil-kecilan, warung, menjadi pembantu rumah tangga, salon, pegawai, penjaga toko, buruh pabrik, berdagang di pasar dan sebagainya. Berdasarkan penelitian dari Lestari dan Agusta (2013), program Simpan Pinjam Kelompok Perempuan (SPP) memberikan kesempatan bagi perempuan untuk berperan pada sektor publik dengan membuka berbagai peluang usaha, keterlibatan perempuan di sektor publik tersebut dapat membuka peluang mereka untuk turut aktif dalam pembangunan. Hal ini sejalan dengan penelitian dari Azzahra et al. (2017), bahwa terjadi perubahan struktur nafkah berupa pergeseran sumber nafkah dari perkebunan karet menjadi perkebunan kelapa sawit akibat dari adanya ekspansi perkebunan kelapa sawit. Selain itu, juga terjadi perubahan kerja perempuan dari sektor domestik ke sektor publik.

Menurut Rahayu dan Darsana (2019), perempuan yang turut berpartisipasi dalam berbagai aspek kehidupan saat ini bukan hanya ingin adanya persamaan hak antara perempuan dan laki-laki saja, tetapi juga menunjukkan fungsinya dalam pembangunan masyarakat. Kondisi ekonomi keluarga merupakan faktor pendorong utama perempuan untuk bekerja, sehingga waktu yang dicurahkan utnuk kegiatan rumah tangga akan berkurang dan diperlukan adanya pembagian kerja di antara seluruh anggota rumah tangga. Para perempuan yang berperan ganda memiliki keuntungan, yaitu menambah penghasilan dan pengalaman untuk mengembangkan diri sendiri menjadi lebih baik dari sebelumnya. Hal ini sejalan dengan penelitian dari Gustavsson (2020) yang menyatakan bahwa kehidupan perempuan dalam dunia bisnis ekonomi, tidak dapat dipisahkan hubungannya dengan keluarga (relation to the life of the family). Perempuan menjalankan kegiatan ekonomi sebagaimana juga pria, utamanya dimotivasi oleh keinginan untuk mengamankan masa depan keluarga (desire to secure the future of the families). Menurut Pesik et al. (2016), perempuan yang terlibat dalam pasar kerja atau bekerja sampingan di sektor non pertanian memiliki tujuan untuk mencari nafkah demi kelangsungan ekonomi rumah tangga. Berdasarkan hasil penelitian dari Djangaopa et al. (2018), konsekuensi dari proporsi curahan kerja yang besar dari anggota rumah tangga pada aktivitas kerjanya membuat kontribusi pendapatan setiap anggota rumah tangga tersebut juga besar. Hal ini menunjukkan bahwa setiap anggota rumah tangga yang bekerja bersama-sama mencari nafkah untuk memenuhi kebutuhan hidup.

Peningkatan partisipasi kerja perempuan juga terjadi di Kota Banjarmasin. Berdasarkan data dari BPS Kota Banjarmasin (2019), Tingkat Partisiasi Angkatan Kerja (TPAK) penduduk laki-laki pada tahun 2019 yaitu sebesar 78,62 persen, sedangkan TPAK penduduk perempuan pada tahun 2019 yaitu sebesar 53,80 persen. TPAK perempuan ini semakin meningkat dibandingkan dengan tahun sebelumnya, kemungkinan karena tuntutan ekonomi dalam rumah tangga untuk membantu suami mencari uang. Hal ini tergambar pada kehidupan rumah tangga pedagang pasar terapung. Pasar terapung adalah suatu tempat tradisi jual-beli yang menjadi ciri khas Provinsi Kalimantan Selatan dan telah dikenal oleh dunia. Kota Banjarmasin yang dijuluki Kota Seribu Sungai memiliki banyak tempat wisata yang terdiri dari wisata religi, wisata kuliner, dan tempat rekreasi (BPS Kota Banjarmasin, 2020). Menurut Hendraswati (2016), pasar terapung ini dibuat karena berada di wilayah perairan, banyaknya sungai di Banjarmasin, serta rentang sejarah yang menganggap sungai menjadi basis budaya masyarakat Banjar. Sungai dimanfaatkan masyarakat lokal untuk jalur utama transportasi dan tempat untuk aktivitas perdagangan atau pasar. Aktivitas jual-beli dilakukan di atas sungai dengan menggunakan perahu, sehingga pasar tersebut disebut dengan istilah pasar terapung. Menurut Budiarti et al. (2015), terdapat perbedaan kondisi pedagang yang berada di pasar tradisional darat dengan pedagang di pasar terapung, karena pasar tradisional darat merupakan pasar yang berada di kawasan daratan, sedangkan pasar terapung merupakan pasar yang seluruh aktivitasnya dilakukan di atas air dengan menggunakan perahu. Pedagang di pasar tradisional darat akan lebih mudah mendapatkan pembeli dibandingkan pedagang di pasar terapung. Keterlibatan perempuan dalam sektor publik ditunjukkan dengan perempuan pedagang pasar terapung di Pasar Terapung Kuin Alalak, Kota Banjarmasin. Namun, jika dilihat pada kondisi lapang, terdapat perbedaan ukuran perahu yang digunakan oleh pedagang laki-laki dan perempuan di Pasar Terapung Kuin Alalak. Ukuran perahu yang lebih besar dan bermesin atau dalam Bahasa 
Banjar disebut kelotok digunakan oleh pedagang laki-laki, sedangkan perahu berukuran kecil dan tidak bermesin atau dalam Bahasa Banjar disebut jukung digunakan oleh perempuan pedagang pasar terapung. Laki-laki pedagang pasar terapung menggunakan kelotok sehingga dapat membawa barang dagangan lebih banyak, sedangkan perempuan pedagang pasar terapung menggunakan jukung dan membawa barang dagangan lebih sedikit. Menurut Susanti (2018), perempuan pedagang pasar terapung yang menjual hasil produksi sendiri atau tetangganya disebut $d u k u h$, sedangkan yang membeli dari para $d u k u h$ untuk dijual kembali (tangan kedua) disebut panyambangan. Barang dagangan yang dijual adalah sayur mayur, buahbuahan, segala jenis ikan seperti ikan gabus, ikan peda, dan udang. Berbagai kebutuhan rumah tangga tersedia di pasar terapung, seperti beras dan hasil kebun seperti sayur dan buah-buahan dari kampungkampung sepanjang aliran Sungai Barito dan anak-anak sungainya. Belum terdapat organisasi pedagang pasar terapung secara jelas dan tidak tercatat jumlah pedagang pasar terapung di Pasar Terapung Kuin Alalak, Banjarmasin ini.

Lokasi tempat tinggal mereka yang cukup jauh dari lokasi pasar terapung, perempuan pedagang pasar terapung bergandengan dengan perahu bermesin dan besar yang dimiliki oleh pedagang laki-laki agar tiba di tujuan dalam waktu yang lebih singkat dan merasa lebih aman dari gelombang besar. Aktivitas perdagangan di Pasar Terapung Kuin Alalak dimulai dari sekitar pukul 04.00 hingga 08.00 pagi. Mereka menjual berbagai barang kebutuhan sehari-hari, seperti buah-buahan, sayuran, ikan segar, beras, makanan tradisional, dan barang keperluan sehari-hari lainnya. Meskipun sudah larut malam, para pedagang pasar terapung justru bergegas untuk menyiapkan barang dagangan untuk dijual esok hari di lokasi Pasar Terapung Kuin Alalak. Lokasi tempat tinggal yang cukup jauh, membuat mereka harus berangkat dari rumah sejak dini hari agar sampai di lokasi tepat waktu. Demi meningkatkan ekonomi keluarga khususnya keluarga yang tingkat ekonominya relatif rendah dan berpenghasilan tidak menentu, anggota rumah tangga lainnya ikut dilibatkan untuk membantu memenuhi kebutuhan rumah tangga dan mencapai kelentingan nafkah. Berdasarkan penelitian dari Djangaopa et al. (2018), kontribusi pendapatan yang lebih besar bagi setiap anggota rumah tangga merupakan gambaran dari curahan waktu kerja setiap anggota rumah tangga pada aktivitas kerja tersebut. Perempuan pedagang sayuran memiliki potensi dalam peningkatan pendapatan yang nantinya akan meningkatkan kesejahteraan rumah tangga. Hal ini sejalan dengan penelitian dari Katz (1995) yang membuktikan bahwa proses-proses ekonomi dalam rumah tangga terkait alokasi tenaga kerja dan pendapatan rumah tangga adalah sangat spesifik gender (gender-specific). Hal ini terutama dibuktikan bahwa pengeluaran ekonomi pada setiap rumah tangga, dapat dibedakan pengeluaran perempuan (isteri), pengeluaran laki-laki (suami) dan pengeluaran bersama (joint-expenditure). Hal ini menunjukkan bahwa perempuan perlu memiliki pendapatan yang kuat dikarenakan pengeluaran rumah tangga ternyata genderspecific.

Penelitian dari de Groot et al. (2017) menyatakan bahwa untuk menekan resiko kerentanan nafkah, perempuan pengusaha usaha kecil dan menengah biasanya melakukan strategi multiple micro-enterprises (membangun usaha ganda). Usaha ganda tersebut dikembangkan dari single enterprise (usaha tunggal) yang telah digeluti oleh perempuan pengusaha selama ini. Dikarenakan peran ganda perempuan dalam memenuhi kebutuhan dasar keluarga (basic necessities of the family life), seperti mempersiapkan makan bagi keluarga dan juga kegiatan reproduktif lain di dalam rumah tangga, maka perempuan pengusaha usaha kecil biasanya menghadapi kendala pengembangan kewirausahaan, yang utamanya disebut sebagai "lack of entrepreneurial attitudes". Perempuan memilih untuk mengembangkan usaha yang memiliki pendapatan minimal namun berisiko rendah agar mampu mempertahankan keberlanjutan ekonomi. Dengan kendala ini, usaha yang ditekuni oleh perempuan menjadi sulit berkembang. Hal ini karena perempuan harus mampu menjaga keseimbangan antara mencurahkan waktu dan energi untuk kerja dan keluarga. Menurut Sugiharto et al. (2016), strategi pencarian sumber penghidupan yang ditekuni untuk membiayai kebutuhan seluruh anggota keluarga dalam jangka panjang, baik saat miskin maupun sejahtera disebut strategi nafkah. Menurut Berman et al. (2012), strategi adaptasi menunjukkan bagaimana komunitas pedesaan dapat menghadapi dampak buruk perubahan iklim dengan meningkatkan kemampuan beradaptasi agar hidup berkelanjutan, sedangkan kapasitas adaptif adalah kemampuan untuk mempersiapkan diri untuk beradaptasi terhadap perubahan iklim di masa depan. Kapasitas adaptif sangat diperlukan agar masyarakat memiliki perencanaan adaptasi dengan baik dan mencapai masa depan yang lebih berkelanjutan. Menurut Widiyanto et al. (2010), strategi yang diterapkan oleh rumah tangga berbeda-beda sesuai dengan kondisi dan kepemilikan sumberdaya. Perbedaan ukuran perahu pedagang laki-laki dan perempuan dapat menunjukkan perbedaan skala barang dagangan yang akan berpengaruh pada pendapatan yang mereka peroleh setiap harinya. Oleh karena itu, menarik untuk melihat bagaimana perbandingan struktur nafkah, mekanisme adaptasi nafkah, dan faktor-faktor yang mendukung tercapainya kelentingan nafkah rumah tangga pedagang pasar terapung. 


\section{METODE}

Penelitian ini dilakukan di Pasar Terapung Kuin Alalak, Kota Banjarmasin, Provinsi Kalimantan Selatan. Kegiatan penelitian ini akan dilaksanakan dalam jangka waktu enam bulan. Rangkaian kegiatan terhitung mulai bulan Juli 2020 sampai dengan Januari 2021. Penelitian ini merupakan penelitian dengan pendekatan kuantitatif yang didukung dengan kualitatif. Penelitian kuantitatif dilakukan untuk mendapatkan data berupa angka melalui metode survei penelitian berupa kuesioner sebagai alat pengumpulan data dengan pemilihan responden yakni pedagang pasar terapung di Pasar Terapung Kuin Alalak. Penelitian kualitatif dilakukan untuk mendapatkan data yang bersifat deskriptif berupa fenomena sosial, seperti catatan harian, dokumentasi foto, studi literatur, serta dokumen-dokumen penunjang lainnya. Metode yang digunakan untuk memperoleh data kualitatif adalah dengan melakukan wawancara mendalam (in-depth interview) dibantu dengan panduan wawancara kepada informan serta pengolahan data sekunder dan observasi lapang. Data kualitatif yang disajikan secara deskriptif berguna untuk membuat penjelasan secara sistematis, faktual, dan akurat mengenai fakta-fakta dan sifat-sifat populasi atau daerah tertentu.

Jenis data yang digunakan dalam penelitian ini adalah data primer dan data sekunder. Data primer merupakan data yang didapatkan langsung oleh peneliti sesuai hasil temuan yang didapatkan di lapang. Metode yang digunakan yakni dengan melakukan wawancara terstruktur dengan bantuan kuesioner dan panduan wawancara mendalam yang telah disusun sebelumnya. Responden berjumlah 40 responden yang terdiri dari 20 orang laki-laki dan 20 orang perempuan pedagang pasar terapung. Penentuan responden dilakukan secara sengaja (purposive) karena jumlah pedagang di Pasar Terapung Kuin Alalak tidak diketahui secara pasti. Lebih tepatnya, responden pada penelitian ini adalah pedagang pedagang pasar terapung lakilaki, yang anggota rumah tangga lainnya bekerja dan memperoleh pendapatan bukan dari pasar terapung dan pedagang pasar terapung perempuan, yang anggota rumah tangga lainnya bekerja dan memperoleh pendapatan bukan dari pasar terapung. Pemilihan responden ini bertujuan untuk melihat kontribusi nafkah dari pihak laki-laki dan perempuan dalam setiap rumah tangga pedagang pasar terapung laki-laki dan perempuan, baik dari sektor perdagangan maupun non-perdagangan. Pengumpulan data kualitatif dilakukan dengan menggunakan metode wawancara mendalam kepada informan. Informan dipilih dengan menggunakan metode snowball. Selain itu, metode lain yang digunakan adalah melalui observasi lapang di lokasi penelitian guna melihat fenomena aktual yang terjadi.

Data sekunder berupa gambaran umum lokasi penelitian didapatkan dari hasil dokumentasi dan studi literatur melalui hasil penelitian sebelumnya, dapat berupa jurnal, skripsi, tesis, disertasi, dan karya ilmiah lainnya. Kemudian, data sekunder tersebut digunakan sebagai data pendukung penelitian yaitu menyempurnakan hasil yang didapatkan dari kuesioner. Data sekunder yang diperoleh digunakan sebagai pelengkap dan penguat data primer yang telah didapatkan. Data primer dalam penelitian ini didapatkan dengan menggunakan kuesioner. Pada kuesioner tersebut, analisis yang digunakan dalam penelitian ini yaitu karakteristik rumah tangga pedagang pasar terapung, klasifikasi struktur nafkah (sektor perdagangan dan non perdagangan) dan persentase kontribusi pendapatan dari pihak perempuan dan laki-laki dalam setiap rumah tangga pedagang pasar terapung, mekanisme adaptasi nafkah yang dilakukan, dan faktor-faktor yang mendukung tercapainya kelentingan nafkah rumah tangga ketika mengalami krisis ekonomi. Krisis ekonomi yang melatarbelakangi riset ini adalah krisis yang dipicu oleh pandemi Covid-19. Diduga struktur nafkah rumah tangga pedagang pasar terapung didominasi oleh kontribusi dari perempuan pada sektor perdagangan, terdapat perbedaan mekanisme adaptasi nafkah yang dilakukan rumah tangga pedagang pasar terapung perempuan dan laki-laki, serta terdapat berbagai faktor yang mendukung kelentingan nafkah rumah tangga pedagang pasar terapung perempuan lebih tinggi dibandingkan laki-laki.

Data yang diperoleh dimasukkan ke dalam Microsoft Excel 2016 yang disusun berdasarkan variabel penelitian. Data kuantitatif diolah menggunakan aplikasi Microsoft Excel 2016 dan IBM SPSS Statistics 22. Uji statistik yang digunakan yaitu uji regresi dan uji-t untuk melihat pengaruh faktor-faktor terhadap kelentingan nafkah (lama waktu yang dibutuhkan untuk pulih dari krisis) rumah tangga pedagang pasar terapung. Analisis regresi yang digunakan yaitu analisis regresi linear berganda karena mengukur pengaruh antara lebih dari satu variabel prediktor (variabel bebas) terhadap variabel terikat. Sementara itu, data kualitatif dianalisis melalui tiga tahapan yaitu reduksi data, penyajian data, dan verifikasi data. Penyajian data kuantitatif dan kualitatif dibuat kumpulan informasi yang menjadi serangkaian kata-kata untuk disajikan dalam laporan dalam bentuk narasi, diagram, maupun gambar. Terakhir, peneliti menarik kesimpulan yang sesuai dengan rumusan masalah dan tujuan penelitian. 


\section{HASIL DAN PEMBAHASAN}

\section{Gambaran Umum Lokasi Penelitian}

Kota Banjarmasin secara geografis terletak antara $3^{\circ} 16^{\prime} 46^{\prime \prime}$ sampai dengan $3^{\circ} 22^{\prime}$ 54' Lintang Selatan dan $114^{\circ} 31^{\prime}$ 40" sampai dengan 114 39' 55' Bujur Timur (Badan Pusat Statistik Kota Banjarmasin, 2020). Menurut Sugianti (2017), sungai menjadi kebutuhan penting bagi masyarakatnya, seperti mandi, mencuci, mencari ikan, sarana transportasi hingga sarana aktivitas perdagangan. Berdasarkan faktor geografis, sungaisungai di daerah Kalimantan Selatan khususnya Kota Banjarmasin inilah yang selama beratus-ratus tahun telah menyatu dengan cara hidup dan kebiasaan masyarakat, kebiasaan dan cara hidup ini sebagai salah satu hasil pertemuan antara masyarakat dengan lingkungan, sungai telah memunculkan sebuah budaya yang tetap dipertahankan hingga saat ini, salah satunya adalah budaya berjualan yang menjadi dasar pemenuhan kebutuhan pokok manusia yang dilakukan dengan menyesuaikan kondisi lingkungan sungai yaitu keberadaan pasar terapung (Sugianti, 2017). Pasar terapung dibuat karena berada di wilayah perairan dan banyaknya sungai yang ada wilayah Banjarmasin serta rentang sejarah panjang yang menganggap sungai menjadi basis budaya masyarakat Banjar. Oleh karena aktivitas jual-belinya dilakukan di atas sungai dengan menaiki perahu, pasarnya pun dinamakan dengan istilah pasar terapung (Hendraswati, 2016). Berdasarkan informasi di lapang, pasar terapung yang dulunya berada di Muara Kuin, kini letaknya berada persis di perbatasan antara Kelurahan Kuin Utara dan Alalak Selatan, Kota Banjarmasin. Pasar tersebut bernama Pasar Terapung Muara Kuin yang kini berubah nama menjadi Pasar Terapung Kuin Alalak. Penamaan pasar diambil dari tiga lokasi asal, yaitu Pasar Tarapung Alalak Selatan, Alalak Tengah, dan Kuin Utara.

Menurut Wijaya dan Kwanda (2019), pasar terapung ini telah muncul sejak abad ke-14 secara alami, sebelum Kerajaan Banjar berdiri di tahun 1595. Pasar terapung ini merupakan bagian dari Pelabuhan Sungai Bandarmasih yaitu aliran Sungai Barito, dari Sungai Kuin hingga Muara Sungai Kelayan. Posisi pasar terapung yang berada di pertemuan beberapa anak sungai inilah yang menjadikan pasar ini merupakan lokasi yang strategis untuk berdagang. Pada masa itu, belum terdapat infrastruktur jalan daratan sehingga masyarakat hanya bergantung pada perahu sebagai alat transportasi untuk beraktivitas di atas sungai. Lokasi pasar terapung yang berada di pinggiran sungai dan berdekatan dengan pemukiman menyebabkan kondisi ekologi pasar terapung terlihat padat. Menurut Pradana (2020), akses menuju pasar terapung menjadi hal yang perlu diperhatikan, karena keindahan pasar terapung hanya bisa dinikmati di atas perahu saja, sedangkan masyarakat dan pengunjung yang ingin menikmati dari daratan masih sulit. Hal ini karena keberadaan pemukiman dan perusahaan pengelolaan kayu yang menutup pemandangan ke arah pasar terapung.

Berdasarkan informasi di lapang, belum terdapat organisasi pedagang pasar terapung secara jelas dan tidak tercatat jumlah pedagang pasar terapung di Pasar Terapung Kuin Alalak ini. Namun, salah satu pedagang menyatakan jumlah pedagang di Pasar Terapung Kuin Alalak ini berkisar 150 hingga 200 pedagang. Mayoritas para pedagang pasar terapung adalah perempuan. Mereka menjual berbagai kebutuhan sehari-hari, seperti sayuran, buah-buahan, beras, makanan dan minuman tradisional, hingga bahan bakar minyak (BBM). Pendapatan mereka sehari-hari berkisar dari 30.000 hingga 100.000 rupiah bergantung pada jumlah barang yang dibawa, musim, dan kondisi cuaca. Pendapatan akan didapat lebih banyak ketika musim buah-buahan. Kondisi krisis berupa kejutan (shock) yang dialami rumah tangga pedagang pasar terapung yaitu bersumber dari pendapatan yang tidak menentu karena produk pertanian bersifat musiman, mudah busuk dan tidak tahan lama disimpan di suhu ruangan. Mereka tidak memiliki lemari pendingin atau kulkas, sehingga tidak bisa menyimpan produk tersebut agar tetap dalam kondisi segar. Adanya pandemi Covid-19 menyebabkan pendapatan mereka menurun dibandingkan dengan sebelumnya karena terjadi penurunan daya beli masyarakat. Pendapatan yang menurun juga dirasakan oleh seluruh anggota rumah tangga pedagang pasar terapung yang memiliki pekerjaan tidak tetap. Keadaan ini menyebabkan tekanan (stress) bagi ekonomi rumah tangga. Mereka harus melakukan berbagai strategi agar dapat terus melanjutkan hidup.

\section{Struktur Nafkah}

Struktur nafkah merupakan komposisi pendapatan dari berbagai aktivitas nafkah yang dilakukan oleh seluruh anggota rumah tangga. Nafkah mencakup pendapatan, baik uang tunai (cash) maupun bentuk lainnya seperti institusi sosial (kerabat, keluarga, perkampungan, desa dan sebagainya), hubungan gender, dan hak milik yang diperlukan untuk mendukung dan mempertahankan yang diberikan standar kehidupan. Pendapatan dalam rumah tangga pedesaan bervariasi dari tahun ke tahun tergantung pada hasil produksi pertanian dan harga yang diperoleh untuk hasil penjualan. Diversifikasi nafkah yang dilakukan oleh setiap rumah tangga 
ditentukan oleh adanya perbedaan musim, pasar tenaga kerja yang berbeda, strategi risiko, perilaku mengatasi, ketidaksempurnaan pasar kredit, dan tabungan dan strategi investasi antar waktu (Ellis, 1998). Menurut Mardiyaningsih et al. (2010), struktur nafkah berkaitan dengan sumber nafkah yang ada di pedesaan, struktur jaminan sosial, kelembagaan atau pengaturan nafkah dan bentuk pola adaptasi nafkah atau strategi nafkah.

Struktur nafkah rumah tangga pedagang pasar terapung terbentuk dari berbagai sumber nafkah, yaitu berasal dari sektor perdagangan maupun non-perdagangan. Pendapatan sektor perdagangan merupakan pendapatan yang diperoleh dari kegiatan berdagang di Pasar Terapung Kuin Alalak dan pasar tradisional darat, sedangkan pendapatan sektor non-perdagangan merupakan pendapatan yang diperoleh dari kegiatan selain berdagang, seperti misalnya PNS, karyawan swasta, buruh bangunan, petani, dan buruh tani. Struktur nafkah pada penelitian ini akan melihat persentase kontribusi nafkah dari setiap anggota rumah tangga, baik perempuan maupun laki-laki terhadap struktur nafkah setiap rumah tangga pedagang pasar terapung. Menurut Meert et al. (2005), diversifikasi nafkah adalah salah satu bentuk strategi untuk mengatasi masalah keuangan rumah tangga pertanian. trategi dapat dikembangkan secara optimal ditentukan oleh faktor-faktor seperti komposisi rumah tangga, usia dan tingkat pendidikan anggota rumah tangga. Kekuatan modal sosial dan jaringan sosial juga penting, yang menunjukkan akses terhadap kontak, pencarian informasi dan sumber pengetahuan serta sikap profesional. Penelitian ini mengklasifikasi pedagang menjadi pedagang pasar terapung laki-laki dan perempuan atas dasar adanya perbedaan yang dapat terlihat dari ukuran perahu yang digunakan. Berikut ini adalah gambaran struktur nafkah rumah tangga pedagang pasar terapung laki-laki dan perempuan.

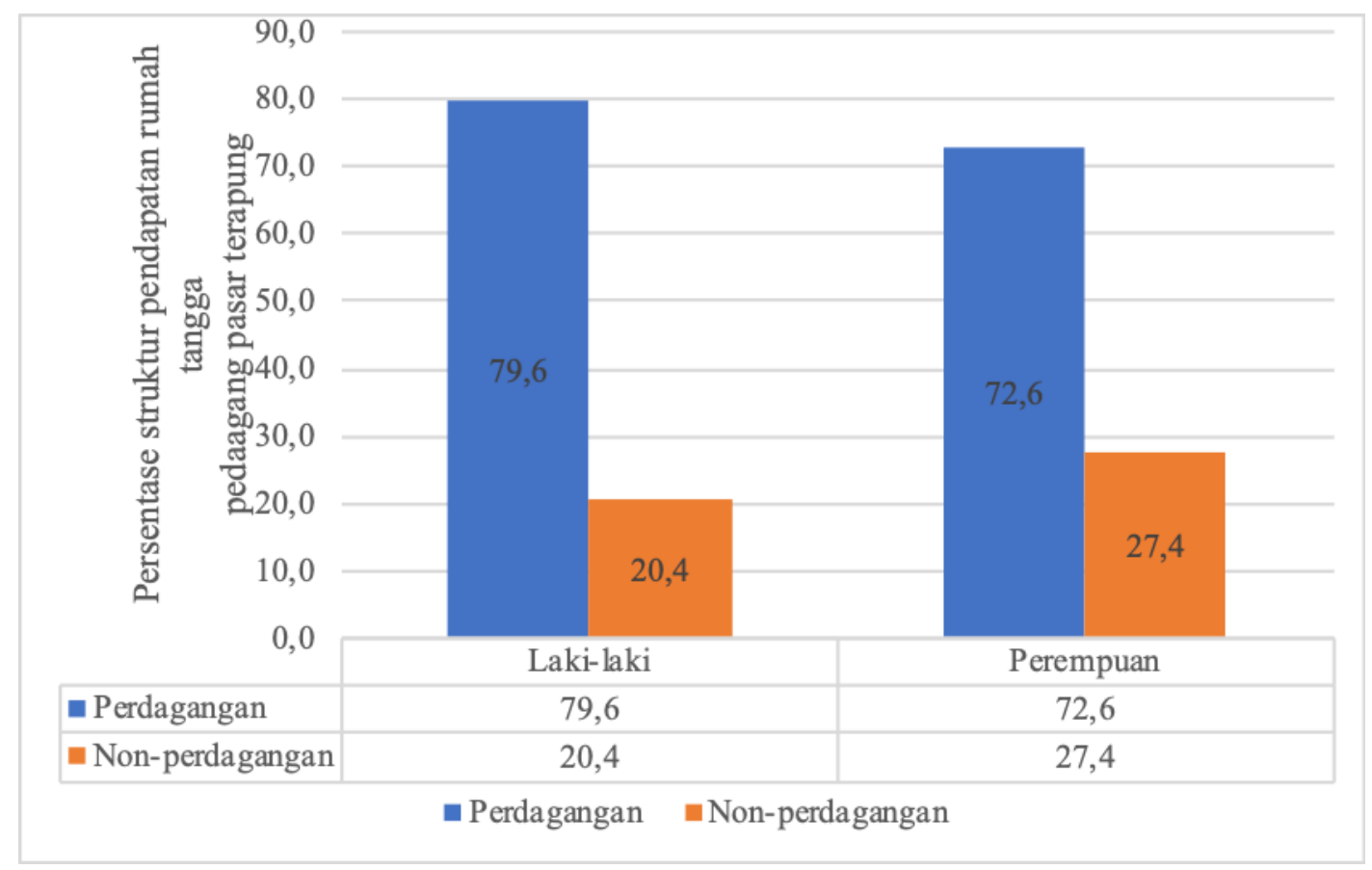

Gambar 1. Persentase struktur pendapatan rumah tangga pedagang di Pasar Terapung Kuin Alalak, Banjarmasin menurut gender per tahun 2020

Gambar 1 menunjukkan bahwa sumber pendapatan pada rumah tangga pedagang pasar terapung didominasi oleh sektor perdagangan yaitu sebesar 79,6 persen pada pendapatan rumah tangga pedagang laki-laki dan 72,6 persen pada pendapatan rumah tangga perempuan pedagang pasar terapung. Pendapatan yang diperoleh dari sektor perdagangan didominasi oleh pendapatan yang merupakan hasil dari berdagang di Pasar Terapung Kuin Alalak yang dilakukan oleh responden laki-laki dan perempuan. Berdasarkan hasil data yang didapatkan di lapangan, pendapatan harian yang diperoleh pedagang pasar terapung laki-laki memang lebih besar dibandingkan dengan pendapatan harian pedagang pasar terapung perempuan, rata-rata pendapatan pedagang pasar terapung laki-laki per harinya adalah sekitar Rp 75.000,- hingga Rp 150.000,- sedangkan rata-rata pendapatan pedagang pasar terapung perempuan per harinya adalah sekitar Rp 40.000,- hingga Rp $100.000,-$. Hal ini tentu dipengaruhi oleh skala barang dagangan yang dijual dan ukuran perahu yang digunakan, mayoritas pedagang pasar terapung laki-laki adalah pedagang grosir karena dengan perahu yang besar dan bermesin mereka mampu membawa barang dagangan dalam jumlah yang banyak, sedangkan 
mayoritas perempuan merupakan pedagang partai atau eceran karena perahu yang kecil dan tidak bermesin sehingga barang yang diperdagangkan dalam jumlah yang terbatas. Secara fisik, laki-laki lebih kuat untuk menyalakan mesin dan menngangkat barang yang berukuran besar, sedangkan perempuan hanya berjualan sayur dan buah yang berukuran kecil karena tidak kuat secara fisik. Berdasarkan informasi yang di dapatkan di lapangan, alasan mereka untuk menjadi pedagang pasar terapung yaitu karena tingkat pendidikan dan keterampilan mereka yang rendah dan hanya berdagang yang bisa mereka lakukan. Selain itu, turun-temurun dari orangtua dan kepemilikan alat transportasi hanya berupa perahu juga menjadi alasan mereka menjadi seorang pedagang pasar terapung.

\section{Struktur Nafkah Rumah Tangga Laki-Laki Pedagang Pasar Terapung}

Pendapatan yang berasal dari sektor perdagangan sangat diandalkan oleh rumah tangga pedagang pasar terapung laki-laki, karena mayoritas anggota rumah tangga yang bekerja adalah sebagai pedagang, baik pedagang di pasar terapung, di rumah, maupun di pasar tradisional darat. Selain itu, rumah tangga pedagang pasar terapung laki-laki juga memanfaatkan pendapatan dari sektor non-perdagangan, seperti misalnya dari bekerja sebagai buruh bangunan, mekanik, dan lain-lain. Berikut ini adalah rincian persentase kontribusi pendapatan masing-masing anggota rumah tangga terhadap struktur nafkah rumah tangga pedagang pasar terapung laki-laki pada sektor perdagangan dan non-perdagangan.

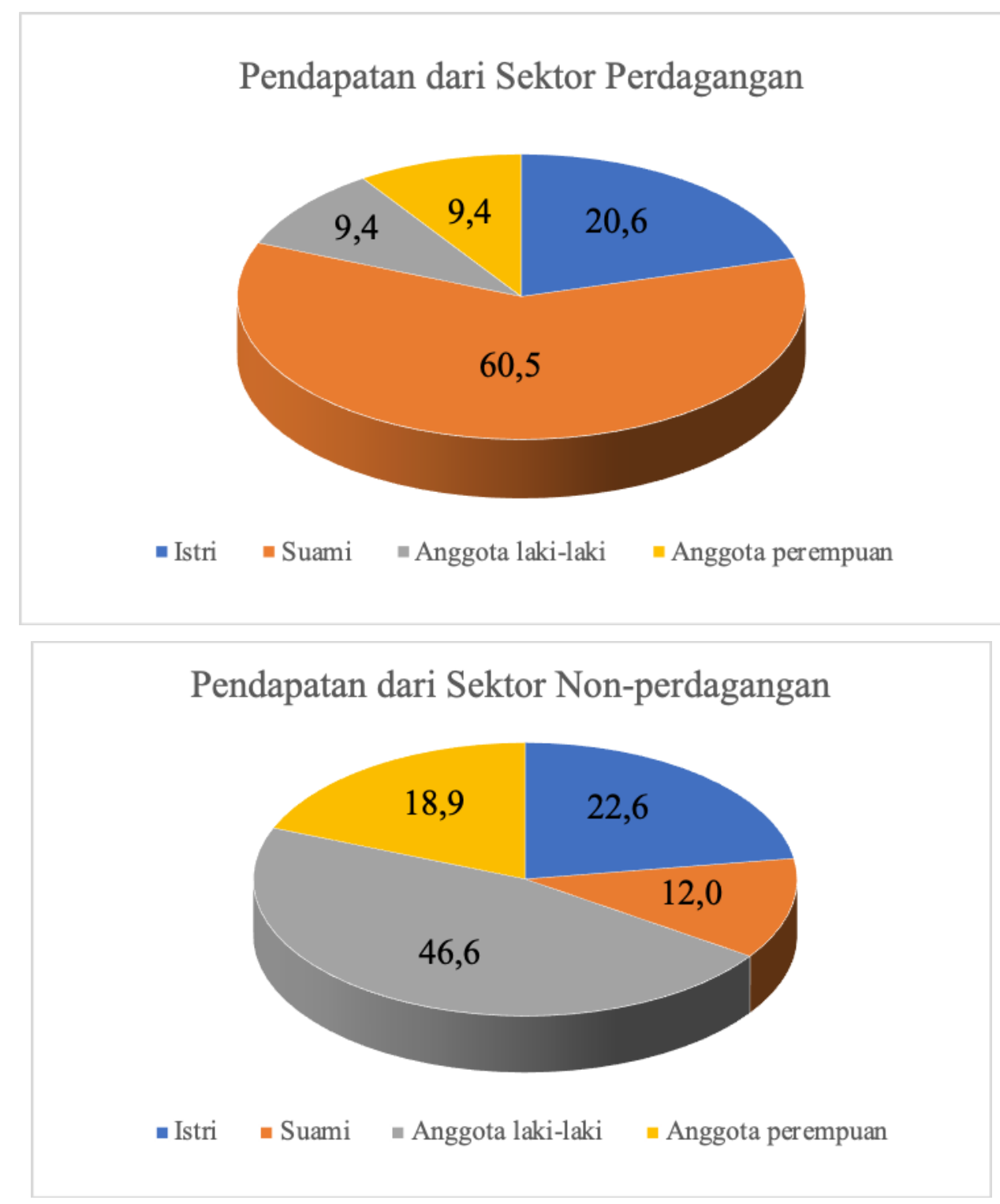

Gambar 2. Persentase kontribusi masing-masing anggota rumah tangga terhadap struktur nafkah rumah tangga pedagang laki-laki, menurut sektor perdagangan dan non-perdagangan di Pasar Terapung Kuin Alalak, Banjarmasin 
Gambar 2 menunjukkan bahwa kontribusi pendapatan pada sektor perdagangan didominasi oleh pendapatan dari pihak suami, yang berdagang di Pasar Terapung Kuin Alalak yaitu sebesar 60,5 persen dari total seluruh pendapatan rumah tangga dari sektor perdagangan. Hal ini menunjukkan bahwa pendapatan dari sektor perdagangan sangat diandalkan bagi pemenuhan kebutuhan rumah tangga. Selain pendapatan dari sektor perdagangan, rumah tangga pedagang pasar terapung laki-laki juga memanfaatkan pendapatan yang berasal dari sektor non-perdagangan. Hal ini sejalan dengan penelitian dari Meert et al. (2005) yang menyatakan bahwa kontribusi dari berbagai aktifitas nafkah dapat menambah total pendapatan utama dan menstabilkan keuangan rumah tangga. Gambar 2 juga menunjukkan bahwa kontribusi pendapatan pada sektor nonperdagangan didominasi oleh pendapatan dari pihak anggota rumah tangga laki-laki lainnya, yaitu dari anak laki-laki atau menantu laki-laki. Kontribusi tersebut sebesar 46,6 persen dari seluruh pendapatan rumah tangga pedagang pasar terapung laki-laki yang bersumber dari sektor non-perdagangan. Pekerjaan non perdagangan yang biasa dilakukan oleh para anggota rumah tangga laki-laki diantaranya adalah buruh bangunan, mekanik, buruh angkut di pasar, hingga karyawan swasta. Bila dipilah secara gender, maka kontribusi pendapatan non-perdagangan didominasi oleh kontribusi dari pekerja laki-laki dalam rumah tangga. Setidaknya kontribusi dari suami dan anggota rumah tangga laki-laki mendominasi pekerjaan di sektor tersebut. Perempuan relatif tidak dominan dalam pekerjaan di sektor non-perdagangan.

\section{Struktur Nafkah Rumah Tangga Perempuan Pedagang Pasar Terapung}

Stereotype yang berlaku umum di masyarakat yang menyebutkan bahwa pihak laki-laki yang menjadi kepala rumah tangga yang harus memenuhi nafkah rumah tangga untuk kebutuhan sehari-hari. Namun pada kasus rumah tangga pedagang pasar terapung perempuan ini, kontribusi nafkah dari pihak perempuan (istri) yang menjadi pedagang pasar terapung ini lebih besar dibandingkan dengan kontribusi dari anggota rumah tangga lainnya. Pendapatan tersebut digunakan oleh rumah tangga pedagang pasar terapung perempuan untuk memenuhi kebutuhan rumah tangga sehari-hari. Pendapatan yang berasal dari sektor perdagangan yang diperoleh oleh pihak istri sangat diandalkan oleh rumah tangga pedagang pasar terapung perempuan, karena sebagian besar nafkah diperoleh dari hasil berdagang di Pasar Terapung Kuin Alalak dan pasar tradisional darat. Selain itu, rumah tangga pedagang pasar terapung perempuan juga memanfaatkan pendapatan anggota rumah tangga lainnya dari sektor non-perdagangan, seperti petani, bertani, dan buruh bangunan. Pada sektor non-perdagangan, mayoritas pendapatan disumbangkan oleh laki-laki, baik suami maupun anggota rumah tangga laki-laki lainnya. Berikut ini adalah rincian persentase kontribusi pendapatan dari masing-masing anggota rumah tangga perempuan pedagang pasar terapung pada sektor perdagangan dan non-perdagangan.

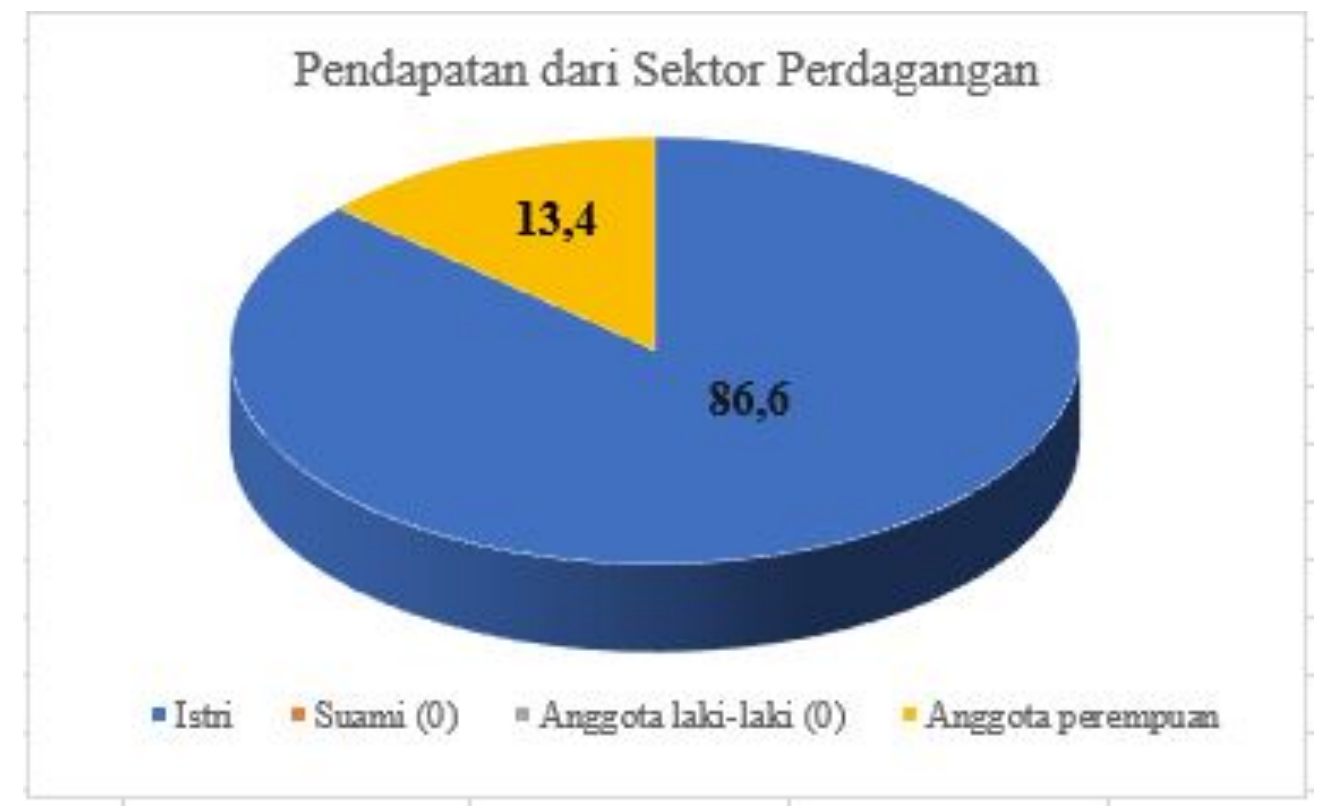




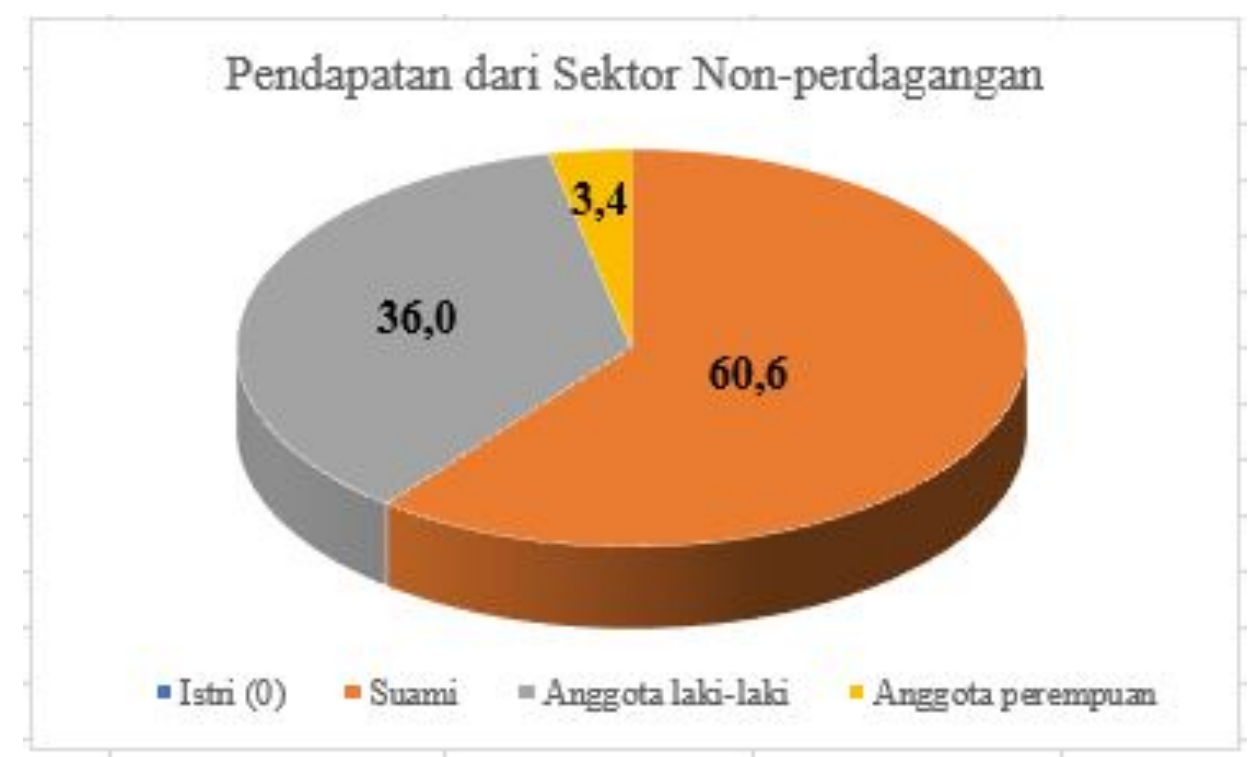

Gambar 3. Persentase kontribusi masing-masing anggota rumah tangga terhadap struktur nafkah rumah tangga perempuan pedagang pasar terapung, menurut sektor perdagangan dan non-perdagangan di Pasar Terapung Kuin Alalak, Banjarmasin, 2020

Gambar 3 menunjukkan bahwa persentase kontribusi pendapatan pada sektor perdagangan didominasi oleh pendapatan dari pihak istri, yang berdagang di Pasar Terapung Kuin Alalak yaitu sebesar 86,6 persen dari total seluruh pendapatan rumah tangga dari sektor perdagangan. Hal ini menunjukkan bahwa pemenuhan kebutuhan rumah tangga perempuan sangat bergantung pada pendapatan yang diperoleh dari pihak perempuan (istri) yang merupakan pedagang pasar terapung. Hal ini sejalan dengan penelitian Sopamena (2019), yang menunjukkan bahwa meningkatnya peran perempuan memberikan dampak positif bagi penerimaan rumah tangga. Selain pendapatan dari sektor perdagangan, rumah tangga pedagang pasar terapung perempuan juga memanfaatkan pendapatan dari sektor perdagangan. Gambar 3 juga menunjukkan bahwa kontribusi terbesar pada sektor non-perdagangan disumbangkan oleh suami, yaitu sebesar 60,6 persen dari total pendapatan rumah tangga pedagang pasar terapung perempuan pada sektor non-perdagangan. Suami dari pedagang pasar terapung perempuan mayoritas bekerja sebagai petani atau buruh tani, dan buruh bangunan. Menurut informasi yang didapatkan di lapangan, pendapatan dari pekerjaan ini berjumlah sedikit karena dilakukan oleh suami pedagang pasar terapung perempuan hanya jika ada yang meminta, atau apabila dalam keadaan kekurangan ekonomi sehingga mencari penghasilan tambahan dari bekerja sebagai buruh bangunan tersebut.

Persentase kontribusi dalam struktur nafkah rumah tangga pedagang pasar terapung ini menunjukkan adanya pembagian kerja yang dilakukan oleh setiap anggota rumah tangga, baik laki-laki maupun perempuan memiliki kesempatan untuk memberikan kontribusi terhadap pendapatan rumah tangga. Hal ini sejalan dengan Durkheim (1960) yang menyatakan bahwa salah satu bentuk pembagian kerja yaitu dalam rumah tangga, karena masing-masing anggota laki-laki dan perempuan memiliki kesempatan untuk berkontribusi dalam rumah tangga, baik kegiatan produksi (ekonomi) maupun kegiatan reproduksi (non-ekonomi). Agar tercipta hubungan kerjasama yang baik, pembagian kerja dapat disesuaikan dengan karakter yang berbeda dan spesialisasi yang tepat.

\section{Mekanisme Adaptasi Nafkah}

Mekanisme adaptasi nafkah yang dilakukan oleh rumah tangga pedagang pasar terapung adalah mekanisme adaptasi ekonomi dan sosial. Mekanisme adaptasi ekonomi merupakan strategi yang dilakukan oleh rumah tangga pedagang pasar terapung untuk meningkatkan pendapatan rumah tangga. Strategi ini dapat dilakukan dengan memanfaatkan berbagai modal yang dimiliki untuk mendapatkan tambahan sumber pendapatan. Mekanisme adaptasi sosial adalah strategi yang dilakukan rumah tangga pedagang pasar terapung dengan cara memanfaatkan relasi sosial yang dimiliki. Menurut Dharmawan et al. (2016), tiga mekanisme adaptasi yang dapat meningkatkan kelentingan adalah mekanisme adaptasi ekonomi seperti diversifikasi sumber nafkah dan penggunaan tabungan rumah tangga, adaptasi ekologi seperti memanfaatkan sumberdaya alam dan meningkatkan penggunaan teknologi pertanian, dan adaptasi sosial seperti meminta bantuan kepada kerabat dekat dan lembaga peminjaman uang. 
Menurut Scoones (1998), strategi untuk mewujudkan sistem nafkah berkelanjutan berkaitan dengan bagaimana rumah tangga dapat memainkan kombinasi modal nafkah yang dimiliki dalam rangka merespon tekanan dan perubahan. Modal nafkah tersebut terdiri dari modal alam, modal finansial, modal manusia, dan modal sosial yang menjadi landasan untuk melakukan strategi nafkah berbeda yang membutuhkan tindakan terkoordinasi. Bentuk mekanisme adaptasi nafkah yang dilakukan rumah tangga pedagang pasar terapung bergantung pada kebutuhan dan modal nafkah yang mereka miliki. Pada bagian ini, akan diidentifikasi bentuk-bentuk mekanisme adaptasi dan urutan prioritas yang dilakukan oleh rumah tangga pedagang pasar terapung laki-laki dan rumah tangga pedagang pasar terapung perempuan dalam merespons krisis berupa kejutan (shock) dan tekanan (stress) yang mereka hadapi.

\section{Mekanisme Adaptasi Nafkah Rumah Tangga Laki-Laki Pedagang Pasar Terapung}

Sebagian besar rumah tangga pedagang pasar terapung laki-laki melakukan mekanisme adaptasi sosial prioritas pertama, yaitu berupa upaya meminjam kepada tetangga (lihat Gambar 4). Mekanisme adaptasi ini dipandang sebagai hal yang paling mungkin dilakukan, karena uang pinjaman lebih cepat didapatkan dan jumlah uang yang dipinjam pun jumlahnya tidak seberapa. Mereka biasanya tidak bersedia meminjam ke bank karena adanya bunga pinjaman yang akan menyulitkan di kemudian hari. Berikut ini adalah rincian urutan prioritas mekanisme adaptasi nafkah yang dilakukan oleh anggota rumah tangga pedagang pasar terapung berjenis kelamin laki-laki.

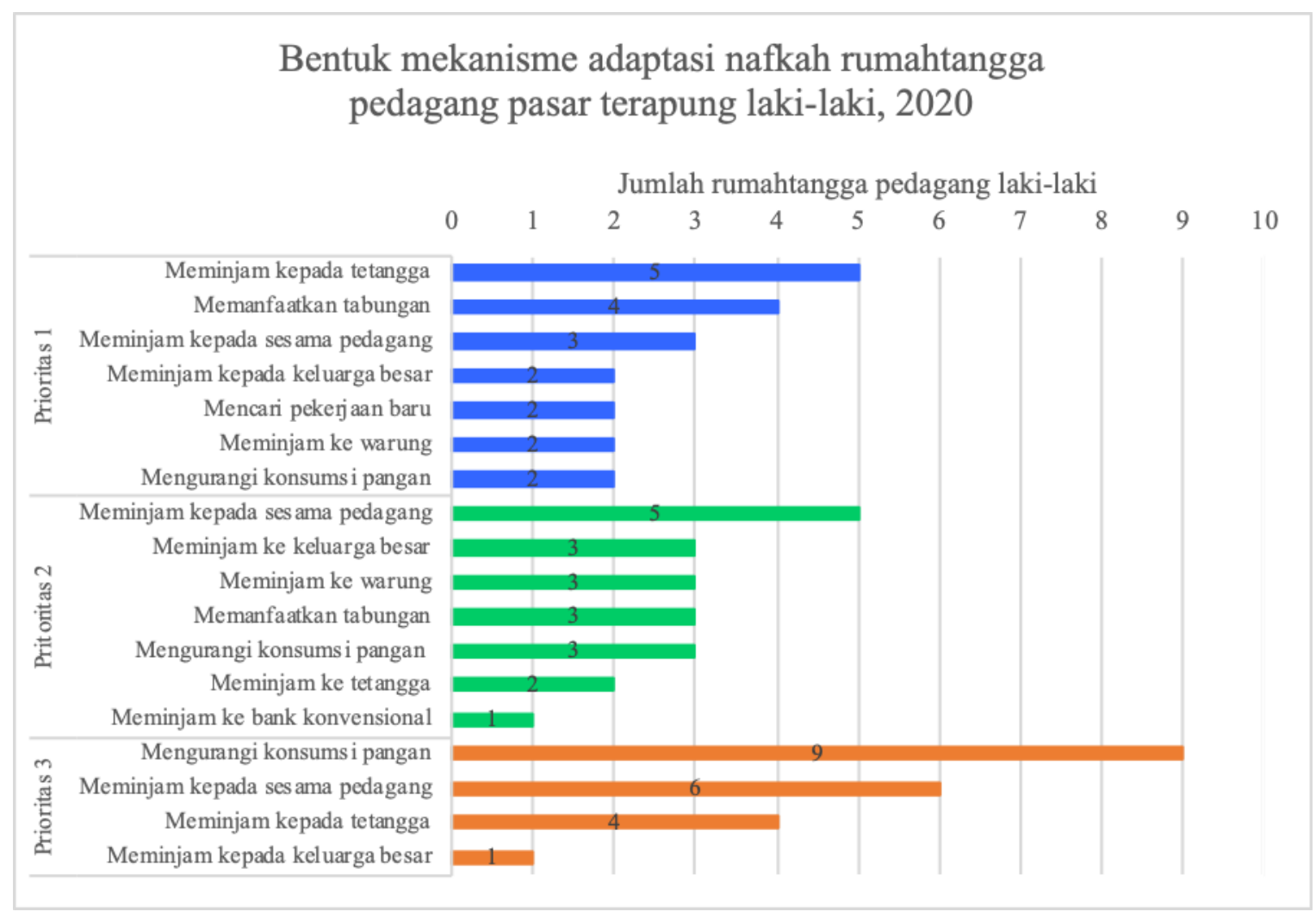

Gambar 4. Jumlah rumah tangga pedagang pasar terapung laki-laki berdasarkan urutan prioritas mekanisme adaptasi nafkah yang dilakukan, 2020

Gambar 4 menunjukkan bahwa bentuk mekanisme adaptasi nafkah prioritas pertama yang paling banyak dilakukan oleh rumah tangga pedagang laki-laki adalah meminjam kepada tetangga. Berdasarkan informasi yang didapatkan di lapang, bentuk strategi ini dilakukan karena waktu yang dibutuhkan untuk mendapatkan uang pinjaman lebih cepat didapat dan merasa jumlah uang yang dipinjam tidak seberapa sehingga tidak perlu meminjam ke bank atau lembaga peminjaman ekonomi lainnya. Pedagang laki-laki memiliki ketergantungan terhadap bantuan orang lain untuk mengatasi krisis ekonomi yang mereka hadapi. Modal sosial mereka yang utama adalah hubungan pertetanggaan yang dijalin secara informal. Modal sosial mereka bukan lembaga keuangan formal. Hal ini sejalan dengan penelitian dari Adger (2003), yang menyatakan bahwa dalam konteks perubahan iklim, banyak potensi risiko yang harus melibatkan intervensi dan perencanaan dengan melakukan strategi adaptasi berupa individu dan komunitas bertindak secara kolektif untuk menghadapi risiko tersebut. 


\section{Mekanisme Adaptasi Nafkah Rumah Tangga Perempuan Pedagang Pasar Terapung}

Sebagian besar rumah tangga pedagang pasar terapung perempuan melakukan mekanisme adaptasi ekonomi dengan prioritas pertama, berupa menekan pengeluaran dengan mengurangi konsumsi pangan rumah tangga. Mekanisme ini sejatinya agak mengkhawatirkan, karena dapat berdampak buruk pada status ekonomi rumah tangga yang bersangkutan. Namun, Cote dan Nightingale (2012) menyatakan, manusia beradaptasi terhadap perubahan sebagai proses heterogen yang harus dipahami melalui hubungan rekursif antara pengetahuan dan konteks yang dimediasi oleh kekuasaan, budaya, dan sejarah. Pada Gambar 5 tampak bentuk-bentuk mekanisme adaptasi nafkah yang dilakukan oleh pedagang pasar terapung perempuan berdasarkan urutan prioritasnya.

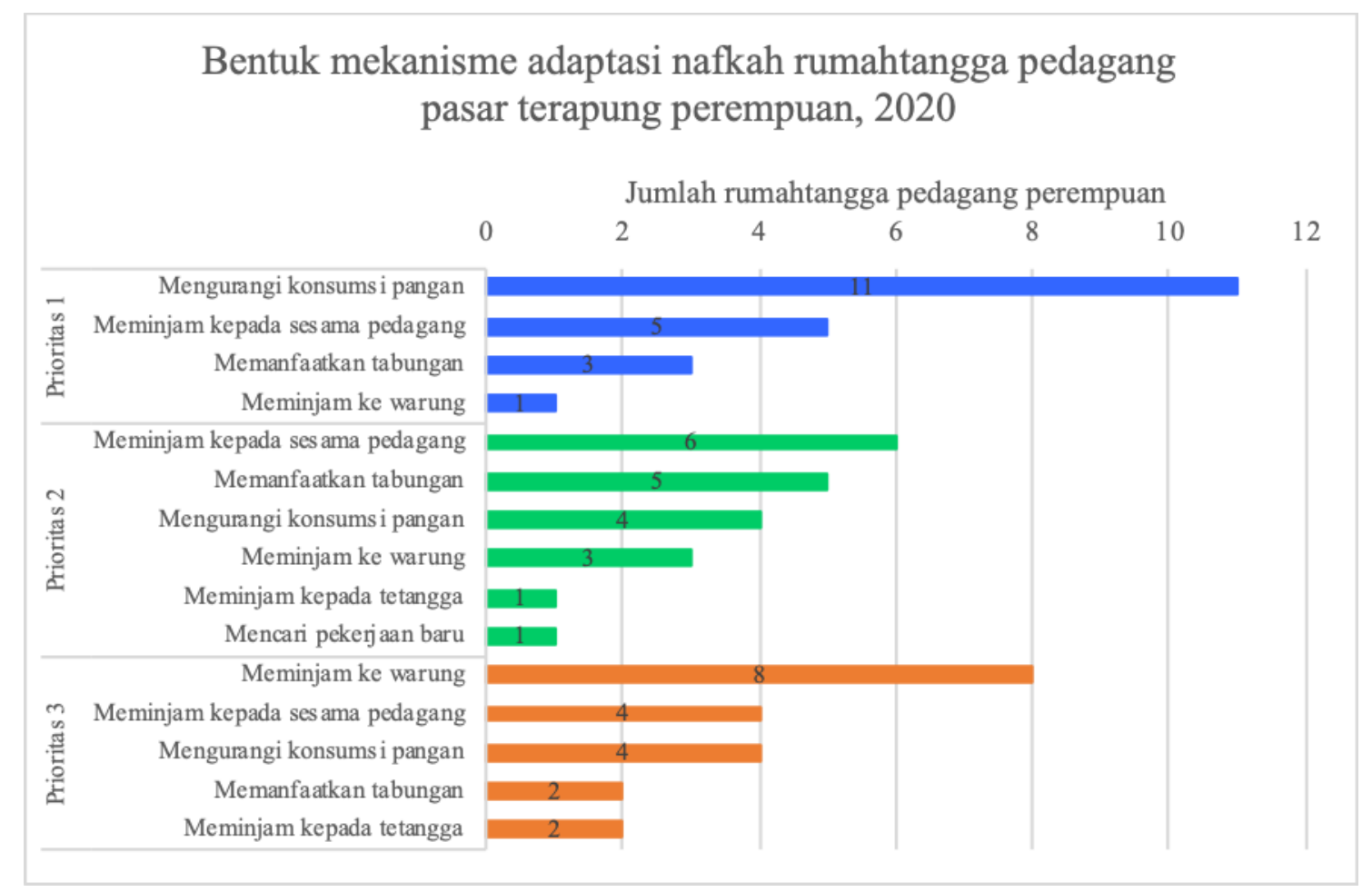

Gambar 5. Jumlah rumah tangga pedagang pasar terapung perempuan berdasarkan urutan prioritas mekanisme adaptasi nafkah yang dilakukan, 2020

Gambar 5 menunjukkan bahwa mengurangi konsumsi pangan adalah hal yang paling banyak dilakukan oleh perempuan pedagang manakala mereka menghadapi krisis atau sekedar shock dalam perekonomian. Mereka melakukan hal ini, karena perempuan pedagang umumnya tidak berani dan merasa malu jika meminjam kepada orang lain, seperti misalnya kepada tetangga, keluarga besar, atau organisasi atau asosiasi peminjaman uang lainnya. Mereka mengatakan, bahwa mereka juga tidak berani meminjam ke lembaga perbankan, karena tidak memiliki aset berharga sebagai jaminan. Sedangkan kepada tetangga atau keluarga besar, mereka beranggapan bahwa keadaan ekonomi warga di lingkungannya juga tidak berbeda jauh dengan kondisi rumah tangga perempuan pedagang pasar terapung ini. Dengan asumsi tersebut, maka yang mereka punya, itulah yang akan mereka manfaatkan untuk bertahan hidup dalam menghadapi krisis. Strategi adaptif dengan mengurangi pengeluaran konsumsi pangan, menunjukkan bahwa rumah tangga perempuan pedagang pasar terapung memilih pendekatan yang sifatnya lebih pada penyesuaian internal. Dengan kata lain, strategi bertahan hidup perempuan pedagang lebih dijalankan terhadap sumberdaya milik sendiri dibandingkan harus memanfaatkan bantuan dari orang lain, hal ini dilakukan agar tidak terjebak dalam ketergantungan.

\section{Kelentingan Nafkah}

Menurut Dharmawan (2007), keberlanjutan sistem penghidupan dan nafkah akan terjadi bila perubahan sosial-ekologi di suatu kawasan tidak menimbulkan shock dan stress (kejutan dan tekanan) yang berlebihan pada sistem nafkah. Artinya, keadaan shock dan stress berupa penurunan modal nafkah pada sumberdaya yang dimiliki membuat setiap rumah tangga harus melakukan kompromi pada sistem nafkah mereka. Berman et al. (2012), menyatakan bahwa kelentingan adalah sebuah proses transformasi terhadap sumberdaya. Proses kelentingan dipahami sebagai penyangga ketika menghadapi perubahan sehingga 
tercapai pembangunan yang berkelanjutan. Menurut Speranza et al. (2014), kelentingan nafkah mengacu pada kemampuan nafkah untuk mengatasi tekanan atau guncangan dan mempertahankan atau meningkatkan sumberdaya yang memiliki fungsi penting. Kelentingan nafkah dicirikan oleh aset aktor dan strategi untuk mempertahankan dan meningkatkan aset, untuk mengatur diri dan belajar. Menurut Dharmawan et al. (2016), kelentingan nafkah diukur dengan kecepatan rumah tangga petani untuk pulih setelah mengalami krisis atau efek yang merugikan dari variabilitas iklim. Kelentingan nafkah sama dengan jumlah kemungkinan strategi mekanisme adaptif yang dimiliki oleh masing-masing responden dan digunakan untuk berupaya kembali ke keadaan normal setelah mengalami krisis. Berdasarkan hasil penelitian di lapangan, terdapat beberapa hal yang menjadi sumber tekanan kerentanan pada rumah tangga pedagang pasar terapung, diantaranya adalah (1) Kejadian pandemi Covid-19 yang menyebabkan menurunnya kelancaran aktivitas perdagangan; (2) Krisis ekonomi secara makro yang diakibatkan oleh dampak pembatasan sosial karena pandemi Covid-19 yang menyebabkan volume dana yang terlibat dalam transaksi menjadi berkurang secara tajam; (3) Berkurangnya pendapatan rumah tangga yang beresiko pada kemiskinan. Keadaan ini menyebabkan tekanan (stress) dan kejutan (shock) bagi rumah tangga pedagang pasar terapung karena masih berlangsung dan tidak diketahui kapan pandemi ini akan berakhir. Seperti yang dituturkan oleh Bapak SPM (62) berikut ini.

"Terutama di saat pandemi, pendapatan berkurang karena orang berbelanja dalam jumlah yang tidak banyak, tidak berbelanja ke pasar, jumlah pedagang pasar tradisional darat yang membeli barang kepada kita juga sedikit. Larangan untuk menyelenggarakan berbagai acara juga menyebabkan pelanggan tidak membeli barang dalam jumlah banyak ke pedagang pasar terapung. Rumah makan juga tidak banyak membeli bahan-bahan makanan seperti biasa, karena jam 8 malam, mereka sudah diminta untuk tutup." (Bapak SPM, Pasar Terapung Kuin Alalak, 29/10/2020)

Kelentingan sistem nafkah rumah tangga dapat dirunut pula dengan menggunakan kerangka pemikiran dari Speranza et al. (2014) yang memberikan tiga parameter kelentingan, yaitu pertama, adalah parameter kapasitas penyangga (buffer capacity) yang diukur melalui indikator jumlah berbagai aset atau modal nafkah yang dimiliki oleh rumah tangga. Kedua, parameter self organization yang diukur melalui jumlah institusi, kerjasama dan jejaring, struktur sosial yang mendukung, serta kepercayaan antara aktor yang saling bekerjasama. Ketiga, parameter capacity for learning, yang diukur melalui kemampuan rumah tangga untuk melakukan pembelajaran secara terus menerus dalam membangun formasi kehidupan sosial sehari-hari, melalui pemahaman akan ancaman yang telah terjadi sebelumnya, dan kemudian melakukan transfer pengetahuan kepada aktor lainnya (Yulian et al. 2017). Sementara itu, tingkat atau kemampuan kelentingan dapat dilihat dari waktu yang diperlukan oleh rumah tangga untuk recovery jika terjadi suatu guncangan (Saraswati dan Dharmawan, 2015). Berdasarkan pengolahan data emik di lapang, kelentingan nafkah rumah tangga pedagang pasar terapung dibagi menjadi dua kategori berdasarkan lama waktu yang dibutuhkan untuk pulih dari krisis, yaitu $<4$ hari dan $\geq 4$ hari. Semakin sedikit atau cepat waktu yang dibutuhkan oleh rumah tangga untuk kembali ke keadaan normal, maka kelentingan nafkah rumah tangga pedagang pasar terapung tersebut dinilai semakin tinggi. Berdasarkan penjelasan di atas, kelentingan nafkah dapat juga dicapai karena adanya berbagai faktor yang mempengaruhi. Faktor-faktor tersebut diuji dengan menggunakan uji regresi linier berganda dan uji-t untuk mengungkap faktor mana yang paling berpengaruh nyata. Berikut ini (Tabel 1.) adalah hasil uji regresi terhadap faktor-faktor yang mempengaruhi kelentingan nafkah rumah tangga pedagang pasar terapung laki-laki dan perempuan.

Tabel 1. Hasil uji regresi faktor-faktor yang mempengaruhi kelentingan nafkah rumah tangga pedagang pasar terapung, Banjarmasin, 2020

\section{Coefficients $^{\mathbf{a}}$}

\begin{tabular}{|c|c|c|c|c|c|c|}
\hline \multirow{2}{*}{\multicolumn{2}{|c|}{ Model }} & \multicolumn{2}{|c|}{$\begin{array}{l}\text { Unstandardized } \\
\text { Coefficients }\end{array}$} & \multirow{2}{*}{$\begin{array}{c}\text { Standardized } \\
\text { Coefficients }\end{array}$} & \multirow[t]{2}{*}{$\mathrm{T}$} & \multirow[t]{2}{*}{ Sig. } \\
\hline & & $\mathrm{B}$ & Std. Error & & & \\
\hline 1 & (Constant) & 3.119 & 5.549 & & .562 & .580 \\
\hline & $\begin{array}{l}\text { Jarak tempuh terhadap } \\
\text { sumberdaya milik bersama } \\
\text { (X1) }\end{array}$ & -.050 & .061 & -.128 & -.818 & .423 \\
\hline & $\begin{array}{l}\text { Jumlah keahlian yang } \\
\text { diselesaikan secara formal oleh } \\
\text { anggota rumah tangga (X2) }\end{array}$ & .425 & .197 & .464 & 2.161 & .043 \\
\hline
\end{tabular}




\begin{tabular}{|c|c|c|c|c|c|}
\hline $\begin{array}{l}\text { Jumlah alokasi tenaga kerja } \\
\text { (X3) }\end{array}$ & .653 & .653 & .206 & 1.000 & .329 \\
\hline $\begin{array}{l}\text { Jumlah keterampilan yang } \\
\text { dimiliki anggota rumah tangga } \\
\text { (X4) }\end{array}$ & -.686 & .979 & -.103 & -.701 & .491 \\
\hline $\begin{array}{l}\text { Jumlah kepemilikan perahu } \\
\text { (X5) }\end{array}$ & .597 & 2.084 & .048 & .286 & .778 \\
\hline Ukuran perahu (X6) & .499 & .286 & .339 & 1.746 & .096 \\
\hline Jumlah pendapatan (X7) & $-9.030 \mathrm{E}-8$ & .000 & -.656 & -2.523 & .020 \\
\hline Jumlah tabungan (X8) & $-4.742 \mathrm{E}-7$ & .000 & -.425 & -1.817 & .084 \\
\hline Jumlah pinjaman (X9) & $-7.955 \mathrm{E}-6$ & .000 & -.124 & -.910 & .374 \\
\hline Jumlah konsumen tetap (X10) & -.164 & .125 & -.210 & -1.305 & .207 \\
\hline $\begin{array}{l}\text { Jumlah organisasi/lembaga } \\
\text { yang diikuti anggota rumah } \\
\text { tangga (X11) }\end{array}$ & .589 & .659 & .158 & .895 & .382 \\
\hline $\begin{array}{l}\text { Jumlah lembaga penyedia } \\
\text { bantuan ekonomi informal } \\
\text { yang diikuti anggota rumah } \\
\text { tangga (X13) }\end{array}$ & 2.288 & 2.230 & .209 & 1.026 & .317 \\
\hline $\begin{array}{l}\text { Jumlah bantuan yang } \\
\text { didapatkan dari lembaga } \\
\text { penyedia bantuan ekonomi } \\
\text { formal (X16) }\end{array}$ & $-4.282 \mathrm{E}-7$ & .000 & -.146 & -.797 & .435 \\
\hline $\begin{array}{l}\text { Jumlah bantuan yang } \\
\text { didapatkan dari lembaga } \\
\text { penyedia bantuan ekonomi } \\
\text { informal (X17) }\end{array}$ & $-5.141 \mathrm{E}-8$ & .000 & -.017 & -.092 & .928 \\
\hline $\begin{array}{l}\text { Jumlah bantuan yang } \\
\text { didapatkan dari lembaga } \\
\text { penyedia bantuan sosial formal } \\
\text { (X18) }\end{array}$ & $8.200 \mathrm{E}-7$ & .000 & .130 & .826 & .419 \\
\hline $\begin{array}{l}\text { Jumlah bantuan yang } \\
\text { didapatkan dari lembaga } \\
\text { penyedia bantuan sosial } \\
\text { informal (X19) }\end{array}$ & $3.259 \mathrm{E}-6$ & .000 & .167 & 1.164 & .258 \\
\hline $\begin{array}{l}\text { Jumlah keberhasilan } \\
\text { menghadapi krisis (X20) }\end{array}$ & .110 & .246 & .092 & .446 & .661 \\
\hline $\begin{array}{l}\text { Frekuensi pertukaran informasi } \\
\text { antar pedagang dalam } \\
\text { menghadapi krisis (X23) }\end{array}$ & .005 & .107 & .008 & .046 & .964 \\
\hline
\end{tabular}

a. Dependent Variable: Lamanya waktu yang dibutuhkan untuk pulih dari krisis (Y)

Sumber : diolah dari data primer, 2020

Hasil uji regresi linier berganda dan uji-t dengan menggunakan taraf kepercayaan sebesar 80 persen memiliki nilai t-tabel yaitu 1,32319. Jika nilai t-hitung lebih besar dibanding nilai t-tabel, maka disimpulkan bahwa terdapat pengaruh antara berbagai faktor yang dianalisis dengan variabel lamanya waktu yang dibutuhkan oleh rumah tangga pedagang pasar terapung untuk pulih dari krisis. Dari Tabel 1, dapat dilihat bahwa faktor yang memiliki nilai t-hitung lebih besar dibanding nilai t-tabel yaitu faktor jumlah keahlian yang diselesaikan secara formal oleh anggota rumah tangga (X2), ukuran perahu (X6), jumlah pendapatan (X7), dan jumlah tabungan (X8). Artinya, faktor-faktor tersebut berpengaruh nyata pada kecepatan pulih rumah tangga pedagang dari krisis ekonomi. Persamaan regresi pada faktor-faktor yang mempengaruhi kelentingan nafkah rumah tangga pedagang Pasar Terapung Kuin Alalak, dengan demikian dirumuskan sebagai $\mathrm{Y}=$ $3.119+0,425\left(\mathrm{X}_{2}\right)+0,499\left(\mathrm{X}_{6}\right)-9.030 \times 10^{-8}\left(\mathrm{X}_{7}\right)-4.742 \times 10^{-7}\left(\mathrm{X}_{8}\right)$. Variabel Y merupakan variabel terikat yaitu tingkat kelentingan nafkah yang dihitung melalui lamanya waktu yang dibutuhkan oleh rumah tangga untuk pulih dari krisis. Faktor-faktor di atas dapat mempengaruhi kelentingan nafkah rumah tangga hingga 
73,7 persen, sedangkan 26,3 persen lainnya dipengaruhi oleh faktor-faktor pendukung kelentingan nafkah lainnya yang tidak diteliti oleh penelitian ini.

\section{Hubungan Jumlah Pendapatan dengan Lama Waktu Yang Dibutuhkan Untuk Pulih Dari Krisis}

Jumlah pendapatan merupakan faktor utama yang paling berpengaruh terhadap kelentingan nafkah (kecepatan pulih dari krisis) rumah tangga pedagang pasar terapung. Faktor ini memiliki nilai t-hitung paling tinggi yaitu sebesar -2.523 dengan tanda minus (-) yang menunjukkan pengaruh ke arah negatif, artinya semakin banyak jumlah pendapatan rumah tangga pedagang pasar terapung, maka akan semakin sedikit atau semakin cepat waktu yang dibutuhkan untuk pulih dari krisis. Berikut ini (Tabel 2.) adalah rincian hubungan jumlah pendapatan dengan lama waktu yang dibutuhkan untuk pulih dari krisis.

Tabel 2. Jumlah dan persentase responden berdasarkan jumlah pendapatan rumah tangga dengan lama waktu yang dibutuhkan untuk pulih dari krisis, Pasar Terapung Banjarmasin, 2020

\begin{tabular}{|c|c|c|c|c|c|c|c|c|c|c|}
\hline \multirow{4}{*}{$\begin{array}{c}\text { Jumlah } \\
\text { pendapatan } \\
\text { (Rp/tahun) }\end{array}$} & \multicolumn{8}{|c|}{ Lama waktu untuk pulih dari krisis } & \multirow{2}{*}{\multicolumn{2}{|c|}{ Total }} \\
\hline & \multicolumn{4}{|c|}{ Laki-laki } & \multicolumn{4}{|c|}{ Perempuan } & & \\
\hline & \multicolumn{2}{|c|}{$<4$ hari } & \multicolumn{2}{|c|}{$\geq 4$ hari } & \multicolumn{2}{|c|}{$<4$ hari } & \multicolumn{2}{|c|}{$\geq 4$ hari } & \multirow[b]{2}{*}{$\mathrm{n}$} & \multirow[b]{2}{*}{$\%$} \\
\hline & $\mathrm{n}$ & $\%$ & $\mathrm{n}$ & $\%$ & $\mathrm{n}$ & $\%$ & $\mathrm{n}$ & $\%$ & & \\
\hline $\begin{array}{l}< \\
\text { Rp25.704.681,00 }\end{array}$ & 0 & 0,0 & 2 & 25,0 & 0 & 0,0 & 4 & 66,7 & 6 & 15,0 \\
\hline $\begin{array}{l}\text { Rp25.704.681,00 } \\
\text { hingga }\end{array}$ & 7 & 58,3 & 6 & 75,0 & 13 & 92,9 & 2 & 33,3 & 28 & 70,0 \\
\hline Rp74.410.085,00 & & & & & & & & & & \\
\hline $\begin{array}{l}\geq \\
\operatorname{Rp} 74.410 .085,00\end{array}$ & 5 & 41,7 & 0 & 0,0 & 1 & 7,1 & 0 & 0,0 & 6 & 15,0 \\
\hline Total & 12 & 100,0 & 8 & 100,0 & 14 & 100,0 & 6 & 100,0 & 40 & 100,0 \\
\hline
\end{tabular}

Sumber : diolah dari data primer, 2020

Berdasarkan informasi pada Tabel 2, dapat diketahui bahwa terdapat enam atau 15 persen rumah tangga pedagang pasar terapung (terdiri dari lima unit didominasi laki dan hanya satu unit merupakan rumah tangga perempuan) memiliki pendapatan diatas Rp74.410.085,00 per tahun. Seluruh rumah tangga tersebut memerlukan waktu kurang dari 4 hari untuk pulih dari krisis. Artinya, lima rumah tangga pedagang laki-laki dan satu unit rumah tangga perempuan pedagang pasar terapung tersebut memiliki kemampuan kelentingan nafkah yang sama. Tampaknya, tingkat pendapatan yang tinggi menyebabkan mereka mudah untuk cepat pulih dari krisis. Sementara itu, pada rumah tangga pedagang yang memiliki jumlah pendapatan antara Rp25.704.681,00 hingga Rp74.410.085,00 per tahun, ada 28 unit rumah tangga atau 70 persen rumah tangga. Komposisi atas 28 unit rumah tangga tersebut adalah 13 rumah tangga pedagang pasar terapung perempuan dan tujuh rumah tangga pedagang laki-laki yang mampu pulih dari krisis kurang dari 4 hari. Disini mulai menarik, terlihat fakta bahwa perempuan pedagang pada golongan pendapatan lapisan menengah terlihat lebih tangguh dan memiliki daya pulih yang lebih baik daripada pedagang pasar terapung berjenis kelamin laki-laki.

Sekilas dapat disimpulkan bahwa pada lapisan menengah, perempuan pedagang jauh memiliki kelentingan yang lebih baik dibandingkan pedagang berjenis laki-laki. Sebanyak delapan rumah tangga lainnya masih memerlukan waktu lebih dari empat hari untuk pulih dari krisis. Selain itu, terdapat enam atau 15 persen rumah tangga yang memiliki jumlah pendapatan kurang dari Rp25.704.681,00 pertahun. Seluruh rumah tangga tersebut memerlukan waktu lebih dari empat hari untuk pulih dari krisis. Hal ini menunjukkan bahwa semakin besar jumlah pendapatan rumah tangga pedagang pasar terapung laki-laki dan perempuan, maka semakin cepat waktu untuk pulih dari keadaan krisis dan semakin tinggi daya lenting. Keadaan pendapatan rumah tangga yang rendah menyebabkan siapapun pedagangnya sulit untuk segera pulih dari krisis, termasuk krisis akibat pandemi Covid-19. 


\section{Hubungan Jumlah Keahlian Yang Diselesaikan Secara Formal oleh Anggota Rumah Tangga dengan Lama Waktu Yang Dibutuhkan Untuk Pulih Dari Krisis}

Jumlah keahlian yang diselesaikan secara formal oleh anggota rumah tangga juga menjadi faktor yang mempengaruhi kelentingan nafkah rumah tangga pedagang pasar terapung yang dihitung dari lamanya waktu yang dibutuhkan untuk pulih dari krisis. Faktor ini memiliki nilai t-hitung sebesar 2.161 dengan tanda positif (+) yang menunjukkan pengaruh ke arah positif, artinya semakin banyak jumlah keahlian yang diselesaikan secara formal oleh anggota rumah tangga, maka akan semakin lama waktu yang dibutuhkan untuk pulih dari krisis. Berikut ini adalah rincian hubungan jumlah keahlian yang diselesaikan secara formal oleh anggota rumah tangga dengan lama waktu yang dibutuhkan untuk pulih dari krisis.

Tabel 3. Jumlah dan persentase responden berdasarkan jumlah keahlian yang diselesaikan secara formal oleh anggota rumah tangga dengan lama waktu yang dibutuhkan untuk pulih dari krisis bagi Pedagang di Pasar Terapung Kuin Alalak, Banjarmasin, 2020

\begin{tabular}{|c|c|c|c|c|c|c|c|c|c|c|}
\hline \multirow{4}{*}{$\begin{array}{l}\text { Jumlah keahlian } \\
\text { yang } \\
\text { diselesaikan } \\
\text { secara formal }\end{array}$} & \multicolumn{8}{|c|}{ Lama waktu untuk pulih dari krisis } & \multirow{3}{*}{\multicolumn{2}{|c|}{ Total }} \\
\hline & \multicolumn{4}{|c|}{ Laki-laki } & \multicolumn{4}{|c|}{ Perempuan } & & \\
\hline & \multicolumn{2}{|c|}{$<4$ hari } & \multicolumn{2}{|c|}{$\geq 4$ hari } & \multicolumn{2}{|c|}{$<4$ hari } & \multicolumn{2}{|c|}{$\geq 4$ hari } & & \\
\hline & $\mathrm{n}$ & $\%$ & $\mathrm{n}$ & $\%$ & $\mathrm{n}$ & $\%$ & $\mathrm{n}$ & $\%$ & $\mathrm{n}$ & $\%$ \\
\hline $\begin{array}{l}<2 \text { keahlian } \\
\text { formal }\end{array}$ & 1 & 8,3 & 1 & 12,5 & 3 & 21,4 & 2 & 33,3 & 7 & 17,5 \\
\hline 2 hingga & & & & & & & & & & \\
\hline $\begin{array}{l}7 \\
\text { formal }\end{array}$ & 7 & 58,3 & 5 & 62,5 & 7 & 50,0 & 3 & 50,0 & 22 & 55,0 \\
\hline $\begin{array}{l}\geq 8 \text { keahlian } \\
\text { formal }\end{array}$ & 4 & 33,3 & 2 & 25,0 & 4 & 28,6 & 1 & 16,7 & 11 & 27,5 \\
\hline Total & 12 & 100,0 & 8 & 100,0 & 14 & 100,0 & 6 & 100,0 & 40 & 100,0 \\
\hline
\end{tabular}

Sumber : diolah dari data primer, 2020

Berdasarkan informasi pada Tabel 3, dapat diketahui bahwa jumlah keahlian yang diselesaikan secara formal oleh anggota rumah tangga pedagang pasar terapung belum tentu dapat membantu nafkah rumah tangga lebih cepat untuk pulih dari krisis, yang terjadi justru sebaliknya. Jumlah keahlian yang diselesaikan secara formal anggota rumah tangga dihitung dari total ijazah pendidikan formal yang telah diperoleh oleh seluruh anggota rumah tangga pedagang pasar terapung, yaitu dari SD/sederajat, SMP/sederajat, SMA/sederajat, hingga Perguruan Tinggi (PT). Jumlah keahlian yang diselesaikan secara formal ini juga berkaitan dengan jumlah tanggungan, semakin banyak jumlah tanggungan maka akan semakin banyak jumlah keahlian yang diselesaikan secara formal oleh anggota rumah tangga. Semakin banyak jumlah anggota rumah tangga maka akan semakin banyak biaya yang harus dikeluarkan untuk memenuhi kebutuhan seluruh anggota rumah tangga tersebut. Jika dilihat dari jumlah anggota rumah tangga pedagang pasar terapung, anggota rumah tangga pedagang laki-laki lebih banyak dibandingkan dengan anggota rumah tangga perempuan pedagang pasar terapung. Hal ini karena sebagian besar pedagang pasar terapung laki-laki memiliki anak dengan jumlah yang lebih banyak dan masih tinggal bersama dengan anak-anaknya atau sampai dengan menantunya, sedangkan sebagian besar pedagang pasar terapung perempuan tidak punya anak dalam jumlah yang banyak dan anak-anak mereka sudah menikah atau tidak satu rumah tangga lagi. Oleh karena itu, semakin banyak jumlah anggota rumah tangga maka akan semakin banyak biaya yang harus dikeluarkan, seperti misalnya untuk biaya pendidikan, uang jajan, biaya transportasi, biaya konsumsi pangan, dan biaya lainnya. Hal ini menunjukkan bahwa pedagang pasar terapung laki-laki lebih banyak memiliki tanggungan dibandingkan dengan pedagang pasar terapung perempuan.

\section{Hubungan Jumlah Tabungan dengan Lama Waktu Yang Dibutuhkan Untuk Pulih Dari Krisis}

Jumlah tabungan yang dimiliki oleh rumah tangga pedagang pasar terapung juga menjadi faktor yang berpengaruh terhadap kelentingan nafkah rumah tangga pedagang pasar terapung. Faktor ini memiliki nilai thitung sebesar -1.817 dengan tanda minus (-) yang menunjukkan pengaruh ke arah negatif, artinya semakin 
besar jumlah tabungan yang dimiliki, maka akan semakin sedikit atau cepat waktu yang dibutuhkan oleh rumah tangga pedagang pasar terapung untuk pulih dari krisis. Hal ini sejalan dengan informasi yang didapatkan di lapang, bahwa beberapa rumah tangga pedagang pasar terapung laki-laki maupun perempuan akan memanfaatkan tabungan yang mereka miliki untuk mengatasi krisis ekonomi. Oleh karena itu, jumlah tabungan ini memiliki pengaruh signifikan terhadap kelentingan nafkah rumah tangga pedagang pasar terapung. Sejumlah tabungan yang dapat disimpan oleh rumah tangga pedagang pasar terapung seringkali dalam bentuk uang dan di simpan di rumah saja, mereka tidak berani untuk menyimpan sejumlah uang di bank karena merasa uang yang biasanya mereka tabung tidak seberapa. Selain itu, mereka juga tidak ingin menyimpan tabungan di bank karena beranggapan bahwa menabung di bank itu tidak dianjurkan dalam agama yang mereka percaya selama ini. Berikut ini adalah rincian hubungan jumlah tabungan rumah tangga pedagang pasar terapung dengan lama waktu yang dibutuhkan untuk pulih dari krisis.

Tabel 4. Jumlah dan persentase responden berdasarkan jumlah tabungan dengan lama waktu yang dibutuhkan untuk pulih dari krisis bagi Pedagang di Pasar Terapung Kuin Alalak, Banjarmasin, 2020

\begin{tabular}{|c|c|c|c|c|c|c|c|c|c|c|}
\hline \multirow{4}{*}{ Jumlah tabungan } & \multicolumn{8}{|c|}{ Lama waktu untuk pulih dari krisis } & \multirow{2}{*}{\multicolumn{2}{|c|}{ Total }} \\
\hline & \multicolumn{4}{|c|}{ Laki-laki } & \multicolumn{4}{|c|}{ Perempuan } & & \\
\hline & \multicolumn{2}{|c|}{$<4$ hari } & \multicolumn{2}{|c|}{$\geq 4$ hari } & \multicolumn{2}{|c|}{$<4$ hari } & \multicolumn{2}{|c|}{$\geq 4$ hari } & \multirow[b]{2}{*}{$\mathrm{n}$} & \multirow[b]{2}{*}{$\%$} \\
\hline & $\mathrm{n}$ & $\%$ & $\mathrm{n}$ & $\%$ & $\mathrm{n}$ & $\%$ & $\mathrm{n}$ & $\%$ & & \\
\hline$\leq \mathrm{Rp} 500,000,00$ & 0 & 0,0 & 0 & 0,0 & 2 & 14,3 & 3 & 50,0 & 5 & 12,5 \\
\hline $\begin{array}{l}\text { Rp500.001,00 } \\
\text { hingga }\end{array}$ & 6 & 50,0 & 8 & 100,0 & 12 & 85,7 & 3 & 50,0 & 29 & 72,5 \\
\hline Rp6.500.000,00 & & & & & & & & & & \\
\hline $\begin{array}{l}\geq \\
\text { Rp6.500.001,00 }\end{array}$ & 6 & 50,0 & 0 & 0,0 & 0 & 0,0 & 0 & 0,0 & 6 & 15,0 \\
\hline Total & 12 & 100,0 & 8 & 100,0 & 14 & 100,0 & 6 & 100,0 & 40 & 100,0 \\
\hline
\end{tabular}

Sumber : diolah dari data primer, 2020

Berdasarkan informasi pada Tabel 4, dapat diketahui bahwa terdapat 6 rumah tangga pedagang pasar terapung laki-laki yang memiliki jumlah tabungan lebih dari Rp6.500.001,00 dan seluruhnya memerlukan waktu kurang dari 4 hari untuk pulih dari krisis. Hal ini menunjukkan bahwa semakin banyak jumlah tabungan yang dimiliki, maka rumah tangga pedagang pasar terapung akan semakin cepat pulih dari keadaan krisis. Rumah tangga pedagang pasar terapung laki-laki dan perempuan dapat menggunakan tabungan yang dimiliki secara langsung ketika mereka mengalami krisis, ketika memerlukan sejumlah uang yang cukup besar dan dalam keadaan genting, seperti misalnya biaya pendidikan dan biaya kesehatan.

\section{Hubungan Ukuran Perahu dengan Lama Waktu Yang Dibutuhkan Untuk Pulih Dari Krisis}

Ukuran perahu yang digunakan oleh pedagang pasar terapung laki-laki dan perempuan juga menjadi faktor yang berpengaruh terhadap kelentingan nafkah yang dihitung dari lamanya waktu yang dibutuhkan untuk pulih dari krisis. Faktor ini memiliki nilai t-hitung sebesar 1.746 dengan tanda positif $(+)$ yang menunjukkan pengaruh ke arah positif, artinya semakin besar ukuran perahu maka akan semakin lama waktu yang dibutuhkan untuk pulih dari krisis. Jenis perahu yang digunakan oleh pedagang pasar terapung adalah perahu bermesin atau dalam Bahasa Banjar disebut kelotok dan perahu yang tidak bermesin dalam Bahasa Banjar disebut jukung. Kelotok berukuran lebih besar, sekitar 6,8 meter hingga 10,2 meter. Sedangkan jukung berukuran 4 meter hingga 5 meter. Kelotok dominan digunakan oleh pedagang pasar terapung laki-laki, sedangkan jukung mayoritas digunakan oleh pedagang pasar terapung perempuan. Ukuran kelotok yang cukup besar membuat pedagang pasar terapung perempuan tidak cukup kuat dan sulit untuk menyalakan mesin dan menggerakkan kelotok. Jukung berukuran lebih kecil dan hanya menggunakan dayung untuk bergerak. Berikut ini adalah rincian hubungan ukuran perahu dengan lama waktu yang dibutuhkan untuk pulih dari krisis. 
Tabel 5. Jumlah dan persentase responden berdasarkan jumlah tabungan dengan lama waktu yang dibutuhkan untuk pulih dari krisis, Pedagang di Pasar Terapung Kuin Alalak, Banjarmasin, 2020

\begin{tabular}{|c|c|c|c|c|c|c|c|c|c|c|}
\hline \multirow{4}{*}{$\begin{array}{l}\text { Ukuran } \\
\text { perahu } \\
\text { (meter) }\end{array}$} & \multicolumn{8}{|c|}{ Lama waktu untuk pulih dari krisis } & \multirow{2}{*}{\multicolumn{2}{|c|}{ Total }} \\
\hline & \multicolumn{4}{|c|}{ Laki-laki } & \multicolumn{4}{|c|}{ Perempuan } & & \\
\hline & \multicolumn{2}{|c|}{$<4$ hari } & \multicolumn{2}{|c|}{$\geq 4$ hari } & \multicolumn{2}{|c|}{$<4$ hari } & \multicolumn{2}{|c|}{$\geq 4$ hari } & \multirow[b]{2}{*}{$\mathrm{n}$} & \multirow[b]{2}{*}{$\%$} \\
\hline & $\mathrm{n}$ & $\%$ & $\mathrm{n}$ & $\%$ & $\mathrm{n}$ & $\%$ & $\mathrm{n}$ & $\%$ & & \\
\hline 4 & 0 & 0,0 & 0 & 0,0 & 6 & 42,9 & 6 & 0,0 & 12 & 30,0 \\
\hline 4,5 & 0 & 0,0 & 0 & 0,0 & 3 & 21,4 & 0 & 0,0 & 3 & 7,5 \\
\hline 5 & 0 & 0,0 & 0 & 0,0 & 2 & 14,3 & 0 & 0,0 & 2 & 5,0 \\
\hline 6,8 & 2 & 16,7 & 4 & 50,0 & 2 & 14,3 & 0 & 0,0 & 8 & 20,0 \\
\hline 8,5 & 6 & 50,0 & 4 & 50,0 & 1 & 7,1 & 0 & 0,0 & 11 & 27,5 \\
\hline 10,2 & 4 & 33,3 & 0 & 0,0 & 0 & 0,0 & 0 & 0,0 & 4 & 10,0 \\
\hline Total & 12 & 100,0 & 8 & 100,0 & 14 & 100,0 & 6 & 100,0 & 40 & 100,0 \\
\hline
\end{tabular}

Sumber : diolah dari data primer, 2020

Berdasarkan Tabel 5, rupanya ukuran perahu yang besar tidak menandakan kondisi rumah tangganya lebih cepat untuk pulih dari krisis dibanding pedagang yang menggunakan perahu berukuran lebih kecil, yang terjadi justru sebaliknya. Para perempuan pedagang pasar terapung yang menggunakan perahu kecil tidak bermesin (jukung) justru lebih cepat pulih dari krisis dibanding dengan pedagang pasar terapung laki-laki yang cenderung menggunakan perahu dengan ukuran lebih besar. Hal ini tentu dipengaruhi oleh kemampuan setiap rumah tangga untuk memanfaatkan sumberdaya yang dimiliki, jumlah tanggungan, jumlah pengeluaran, gaya hidup, dan kemampuan rumah tangga untuk mengatur keuangan rumah tangga dengan baik. Mayoritas pedagang pasar terapung yang menggunakan perahu bermesin (kelotok) berukuran besar adalah pedagang laki-laki yang menjadi pedagang grosir dengan jumlah barang dagangan yang dalam jumlah yang banyak, namun barang tersebut didapatkan dengan meminjam barang terlebih dahulu, sehingga memerlukan waktu yang lebih lama untuk mengembalikan pinjaman tersebut, sekitar satu minggu atau lebih. Ketika menghadapi krisis ekonomi, rumah tangga pedagang pasar terapung laki-laki lebih memilih untuk meminjam uang kepada orang lain dibandingkan dengan mengurangi biaya hidup, sedangkan pada perempuan pedagang pasar terapung mayoritas dari mereka merupakan pedagang eceran yang menggunakan perahu tidak bermesin (jukung). Jumlah barang dagangan yang mereka bawa tidak dalam jumlah yang banyak sehingga dapat membeli barang tersebut sedikit demi sedikit dan tidak perlu meminjam barang terlebih dahulu kepada pedagang lain.

Apabila terpaksa meminjam barang terlebih dahulu, para pedagang pasar terapung perempuan ini berusaha untuk segera mengembalikan pinjaman pada hari itu atau paling lambat mengembalikan keesokan harinya. Mereka merasa malu apabila harus melakukan pinjam-meminjam kepada orang lain. Selain itu, pada rumah tangga pedagang pasar terapung perempuan ini lebih memilih untuk mengurangi biaya hidup agar tidak bergantung kepada orang lain. Para perempuan pedagang pasar terapung juga lebih ulet dalam berjualan, karena setelah di pasar terapung, mereka berkeliling ke sungai-sungai kecil untuk menjajakan barang dagangan, tidak jarang juga mereka melanjutkan berdagang di pasar tradisional darat. Hal inilah yang menyebabkan para pedagang eceran pasar terapung perempuan membutuhkan waktu lebih cepat untuk pulih dari krisis dibandingkan dengan pedagang grosir pasar terapung laki-laki. Hal ini sejalan dengan Folke (2006) yang menyatakan bahwa kelentingan tidak hanya tentang menjadi gigih atau kuat terhadap gangguan, tetapi juga tentang peluang membuka dalam hal rekombinasi struktur dan proses, pembaruan sistem dan munculnya berbagai alternatif baru. Meskipun ukuran perahu yang digunakan perempuan pedagang pasar terapung lebih kecil dan tidak bermesin, mereka dapat menumpang bergandengan dengan perahu besar dan bermesin milik pedagang laki-laki. Hal ini mereka lakukan agar tidak kelelahan mendayung karena lokasi tempat tinggal mereka cukup jauh dari lokasi Pasar Terapung Kuin Alalak. Selain itu, mereka lebih merasa aman dari gelombang sungai yang cukup besar serta waktu yang dibutuhkan untuk kembali ke lokasi tempat tinggal akan lebih singkat. Berikut ini adalah kisah hidup seorang perempuan pedagang pasar terapung. 


\section{Box 1. Kisah hidup Ibu JLN (50), pedagang buah rambai}

Ibu JLN adalah seorang pedagang buah-buahan, diantaranya adalah buah semangka dan buah rambai. Buah rambai merupakan buah khas dari hutan Kalimantan yang merupakan makanan favorit bekantan. Bekantan merupakan hewan primata endemik Pulau Kalimantan yang berciri memiliki hidung Panjang dengan rambut berwarna merah kecoklatan. Buah ini juga terkadang di konsumsi oleh warga sekitar untuk dibuat campuran sambal karena rasanya yang asam. Ibu JLN mendapatkan buah rambai ini di Pulau Kembang, yang merupakan pulau bagi para bekantan. Malam hari, Ibu JLN berangkat ke pulau tersebut untuk mencari buah rambai yang jaraknya sekitar 30 kilometer dari lokasi tempat tinggalnya hanya dengan jukung (perahu kecil tidak bermesin). Dengan berjualan buah rambai inilah yang membuatnya berbeda dengan pedagang yang lainnya karena hanya ia yang berjualan buah rambai. Ibu JLN berani mengambil resiko besar karena hanya menggunakan jukung untuk bepergian dalam jarak yang sangat jauh tersebut, terlebih lagi kegiatan tersebut dilakukan pada waktu malam hari ketika suasana sangat gelap dan sangat beresiko bagi keselamatan Ibu JLN. Saat ini, Ibu JLN hanya tinggal bersama suami yang bekerja sebagai buruh tani. Semua anaknya sudah berstatus menikah dan tidak tinggal satu rumah lagi. Beberapa bulan terakhir ini, suami nya sering sakit-sakitan sehingga tidak mampu lagi bekerja. Penghasilan Ibu JLN sangat pas-pasan, sekitar 30.000 hingga 40.000 rupiah per harinya. Di masa pandemi seperti saat ini, penghasilannya juga menurun karena pembeli semakin berkurang. Beliau mengatakan, uang hasil berdagang pasar terapung memang hanya cukup untuk memenuhi kebutuhan pangan sehari-hari ia bersama suami. Hal terpenting baginya adalah suaminya bisa makan dan minum kopi setiap hari. Apabila mengalami krisis ekonomi seperti misalnya barang tidak laku karena pembeli berkurang atau cuaca hujan, beliau memilih untuk mengurangi konsumsi pangan karena tidak ingin meminjam dengan orang lain, apalagi ke bank karena agama tidak memperbolehkan. Diusia nya yang kini sudah tidak muda lagi, ia tetap gigih berjualan sebagai pedagang pasar terapung. Beliau menjadi pedagang pasar terapung karena hanya itu yang bisa beliau lakukan untuk memperoleh pendapatan, ia tidak memiliki keterampilan apapun dan pendidikan yang ditempuhnya rendah. Selain itu, alat transportasi yang ia miliki untuk bepergian hanyalah jukung.

Sumber : Ibu JLN, 50 tahun, pedagang buah rambai

Perempuan pedagang pasar terapung memiliki nilai etos kerja yang tinggi. Usia yang tidak muda lagi, keterbatasan fisik, dan ukuran perahu yang lebih kecil tak menyurutkan semangat dan kerja keras perempuan pedagang pasar terapung untuk terus melanjutkan hidup. Mereka dapat memanfaatkan relasi dengan pedagang laki-laki untuk membantu meningkatkan kelancaran aktivitas perdagangan mereka. Perempuan pedagang pasar terapung menggunakan perahu yang berukuran lebih kecil sehingga mampu lebih gesit bergerak untuk berdagang dan menyusuri sungai-sungai kecil dan menjangkau konsumen secara langsung di pemukiman yang berada di sepanjang aliran sungai. Hasil temuan ini menunjukkan bahwa para pedagang pasar terapung lebih baik memanfaatkan seluruh sumberdaya yang telah dimiliki sendiri secara optimal untuk mengatasi krisis ekonomi rumah tangga dibandingkan jika harus bergantung pada bantuan orang lain atau sumberdaya eksternal.

\section{Gender-Spesific dalam Kelentingan Nafkah Rumah Tangga}

Selama ini rumah tangga adalah basis organisasi nafkah terkecil dalam masyarakat. Rumah tangga selain sebagai income pooling unit, juga berfungsi sebagai organisasi pengatur alokasi sumberdaya manusia (Dharmawan, 2001). Pembahasan tentang organisasi ekonomi dalam rumah tangga menggunakan kerangka pemikiran Durkheim (1960) tentang division of labor, lebih banyak membahas tentang bagaimana alokasi waktu dan beban kerja perempuan dibandingkan laki-laki dalam keseluruhan aktivitas produktif dan reproduktif (Azzahra et al., 2017). Hasil penelitian menunjukkan bahwa kelentingan nafkah yang ditunjukkan oleh perempuan pedagang di pasar apung berbeda dengan kelentingan nafkah yang ditampilkan oleh pedagang berjenis kelamin laki-laki di kawasan yang sama. Secara karakteristik fisik dan teknis perdagangan, laki-laki lebih unggul daripada perempuan dalam menjalankan bisnis perdagangan di pasar terapung, namun ternyata bukti menunjukkan bahwa perempuan jauh lebih ulet, fleksibel, dan lebih cepat mencapai pemulihan ekonomi ketika mengalami krisis. Singkat kata, perempuan pedagang lebih lenting 
dibandingkan laki-laki pedagang pasar terapung dalam membangun sistem nafkah rumah tangga berbasiskan usaha kecil dan menengah perdagangan. Artinya, kelentingan nafkah pengusaha perdagangan di Pasar Terapung Kuin Alalak di Banjarmasin, sesungguhnya adalah gender-specific. Kesimpulan ini selaras dengan kerangka konseptual Katz (1995) yang jauh-jauh hari telah menyimpulkan bahwa proses-proses ekonomi (household economic processes) dalam sistem nafkah rumah tangga antara perempuan dan laki-laki sungguh berbeda. Perbedaan itu, utamanya dikarenakan aspek decision making (pengambilan keputusan) dan pengelolaan hubungan sosial untuk survival yang berbeda. Studi ini juga selaras dengan temuan de Groot et al. (2017) yang mengemukakan bahwa perempuan dan laki-laki memiliki peran penting dalam mencapai tujuan kesejahteraan keluarga dalam bernafkah, tetapi perempuan terbukti lebih ulet dibandingkan laki-laki karena lebih banyak mempertimbangkan resiko dalam berbisnis.

Meskipun selalu dihadapkan pada sebuah kendala struktural yang tak bisa dihindarkan dalam setting sosial bahwa perempuan selalu terikat oleh pemenuhan kebutuhan dasar dan reproduktif (basic necessities and reproductive work of family life) yang membuat perempuan memiliki beban yang relatif tidak ringan. Kenyataan ini juga selaras dengan temuan Gustavsson (2020) mengatakan bahwa kehidupan bisnis ekonomi atau nafkah perempuan tidak dapat dilepaskan dari hubungannya dengan kehidupan keluarga. Hal spesifik lain yang ditemukan oleh studi ini adalah bahwa sekalipun dengan kendala struktural yang dihadapi oleh pedagang perempuan, namun ternyata hal tersebut tidak berimplikasi pada derajat kesejahteraan perempuan pada rumah tangga (costs of women's individual well-being) yang bekerja sebagai pedagang di pasar terapung. Artikel ini menunjukkan bahwa organisasi sumberdaya ekonomi dalam rumah tangga sebagai sebuah sistem nafkah, tidak hanya menunjukkan signifikansi pembagian kerja laki-laki dan perempuan, namun juga membedakan bahwa di antara laki-laki dan perempuan ternyata memiliki daya lenting yang diukur melalui kecepatan pulih dari krisis yang berbeda. Oleh karena itu, studi ini mengajukan sebuah proporsi bahwa dalam rangka membangun sistem penghidupan atau nafkah, sebuah organisasi ekonomi rumah tangga membedakan kemampuan melenting yang berbeda antara perempuan dan laki-laki. Secara singkat, hasil kajian ini mengajukan usulan konseptual ke depan, adanya gendered-spesific terhadap kemampuan daya lenting nafkah di dalam rumah tangga. Dalam hal ini, perempuan memiliki daya lenting yang relatif lebih tinggi daripada laki-laki.

\section{KESIMPULAN}

Berdasarkan hasil analisis dalam penelitian, maka dapat disimpulkan bahwa kontribusi nafkah dari sektor perdagangan sangat dominan dalam struktur nafkah rumah tangga pedagang pasar terapung laki-laki dan perempuan. Stereotype yang berlaku umum di masyarakat yang menyebutkan bahwa pihak laki-laki yang harus memenuhi nafkah rumah tangga untuk kebutuhan sehari-hari nyatanya tidak berlaku bagi rumah tangga pedagang pasar terapung perempuan. Kontribusi nafkah sektor perdagangan dari perempuan pedagang pasar terapung sangat diandalkan dan mendukung pendapatan utama yang dimanfaatkan untuk memenuhi kebutuhan seluruh anggota rumah tangganya. Hal ini menunjukkan bahwa perempuan pedagang pasar terapung merupakan pencari nafkah yang nyata harus diperhitungkan dalam rumah tangga.

Mekanisme adaptasi nafkah yang dilakukan oleh rumah tangga pedagang pasar terapung laki-laki dan perempuan berbeda. Pedagang laki-laki lebih memilih untuk meminjam sejumlah uang kepada orang lain, sedangkan perempuan pedagang pasar terapung memilih untuk mengurangi konsumsi pangan agar mengurangi pengeluaran rumah tangga. Hal ini menunjukkan bahwa pedagang laki-laki memiliki ketergantungan terhadap orang lain dengan meminjam sejumlah uang, sedangkan perempuan pedagang pasar terapung memilih untuk memanfaatkan sumberdaya yang telah dimiliki sendiri dengan baik dibanding jika harus bergantung kepada orang lain.

Kemampuan untuk pulih dari krisis perempuan pedagang pasar terapung lebih baik dibandingkan pedagang laki-laki, terutama pada pedagang terapung lapisan menengah. Faktor-faktor yang mempengaruhi tercapainya kelentingan nafkah yaitu jumlah keahlian yang diselesaikan secara formal oleh anggota rumah tangga,ukuran perahu, jumlah pendapatan, dan jumlah tabungan. Rumah tangga pedagang pasar terapung perempuan lebih banyak menunjukkan waktu untuk pulih dari krisis kurang dari empat hari. Hal ini menunjukkan bahwa perempuan lebih mampu beradaptasi dan memiliki kelentingan yang lebih baik ketika terjadi krisis, baik berupa shock atau stress. Perempuan mampu memanfaatkan sumberdaya milik sendiri untuk mengatasi krisis tersebut. Berdasarkan penelitian ini, dapat disimpulkan bahwa laki-laki yang dikesankan besar belum tentu kuat dalam beradaptasi terhadap krisis, sementara perempuan yang dikesankan kecil dan terbatas sumberdayanya ternyata belum tentu lemah dalam menghadapi krisis. Sebuah krisis ekonomi yang pada tahun 2020 ditandai oleh pandemi Covid-19 yang menghempaskan siapa saja, namun 
bagi perempuan pedagang terapung di Banjarmasin, hal ini disambut dengan ketangguhan yang baik. Hasil penelitian ini menunjukkan bahwa kelentingan nafkah memiliki dimensi gender-spesific yang kuat. Perempuan pedagang pasar terapung memiliki kelentingan yang lebih baik dibandingkan laki-laki pedagang pasar terapung dalam rumah tangganya.

\section{DAFTAR PUSTAKA}

Adger, W. N. (2003). Social capital, collective action, and adaptation to climate change. Economic Geography, 79(4), 387-404. https://doi.org/10.1111/j.1944-8287.2003.tb00220.x

Azzahra, F., Dharmawan, A. H., \& Pandjaitan, N. K. (2017). Perempuan dan resiliensi nafkah rumahtangga petani sawit: analisis dampak ekspansi perkebunan kelapa sawit di Provinsi Jambi. Jurnal Sosiologi Pedesaan, 5(1), 25-35. https://doi.org/https://doi.org/10.22500/sodality.v5il.16269

Badan Pusat Statistik Kota Banjarmasin. (2019). Profil Tenaga Kerja Kota Banjarmasin 2019. In Badan Pusat Statistik Kota Banjarmasin. https://banjarmasinkota.bps.go.id/publication/2020/12/09/806c591ddb9e40a7793925df/profil-tenagakerja-kota-banjarmasin-2019.html

Badan Pusat Statistik Kota Banjarmasin. (2020). Kota Banjarmasin dalam Angka 2020. In Badan Pusat Statistik Kota https://banjarmasinkota.bps.go.id/publication/2020/04/27/ca4ac2ee886fa827fcb67eef/kotabanjarmasin-dalam-angka-2020.html

Berman, R., Quinn, C., \& Paavola, J. (2012). The role of institutions in the transformation of coping capacity to sustainable adaptive capacity. Environmental Development, 1, 86-100. https://doi.org/https://doi.org/10.1016/j.envdev.2012.03.017

Budiarti, Y. L., Akbar, S. N., \& Rachmah, D. N. (2015). Analisis keyakinan diri dan kesejahteraan psikologis pedagang di Pasar Tradisional Darat dan Pasar Terapung Lok Baintan Sungai Tabuk Martapura. Sosio Konsepsia : Jurnal Penelitian Dan Pengembangan Kesejahteraan Sosial, 4(2), 108122. https://doi.org/10.33007/ska.v4i2.117

Cote, M., \& Nightingale, A. J. (2012). Resilience thinking meets social theory: Situating social change in socio-ecological systems (SES) research. Progress in Human Geography, 36(4), 475-489. https://doi.org/https://doi.org/10.1177\%2F0309132511425708

de Groot, J., Mohlakoana, N., Knox, A., \& Bressers, H. (2017). Fuelling women's empowerment? An exploration of the linkages between gender, entrepreneurship and access to energy in the informal food sector. Energy Research and Social Science, 28, 86-97. https://doi.org/10.1016/j.erss.2017.04.004

Dharmawan, A. H. (2001). Farm household livelihood strategies and socio-economic changes in rural Indonesia. Wissenschaftverlag Vauk. Kiel., 124.

Dharmawan, A. H. (2007). Sistem penghidupan dan nafkah pedesaan: pandangan sosiologi nafkah (livelihood sociology) Mazhab Barat dan Mazhab Bogor. Sodality: Jurnal Sosiologi Pedesaan, 1(2), 169-192. https://doi.org/https://doi.org/10.22500/sodality.v1i2.5932

Dharmawan, A. H., Putri, E. I. K., \& Mardiyaningsih, D. I. (2016). Smallholder farmers' resilience in ruralecological crises: Case studies from West Java, Indonesia. International Journal of Sustainability in Economic, Social, and Cultural Context, 12(3), 17-34. https://doi.org/https://doi.org/10.18848/23251115/CGP/v12i03/17-34

Djangaopa, Y., Manginsela, E. P., \& Baroleh, J. (2018). Kontribusi perempuan pedagang sayuran terhadap pendapatan keluarga di Pasar Bahu Manado. Agri-SosioEkonomi, 14(3), 45-54. https://doi.org/10.35791/agrsosek.14.3.2018.21533

Durkheim, E. (1960). The Division of Labor in Society. The Free Press of Glencoe, Illinois. http://fs2.american.edu/dfagel/www/Class Readings/Durkheim/Division Of Labor Final Version.pdf

Ellis, F. (1998). Household strategies and rural livelihood diversification. Journal of Development Studies, 35(1), 1-38. https://doi.org/10.1080/00220389808422553 
Folke, C. (2006). Resilience: The emergence of a perspective for social-ecological systems analyses. Global Environmental Change, 16, 253-267. https://doi.org/10.1016/j.gloenvcha.2006.04.002

Gustavsson, M. (2020). Women's changing productive practices, gender relations and identities in fishing through a critical feminisation perspective. Journal of Rural Studies, 78, 36-46. https://doi.org/10.1016/j.jrurstud.2020.06.006

Hendraswati. (2016). Etos kerja pedagang perempuan Pasar Terapung Lok Baintan di Sungai Martapura. Jurnal Pendidikan Dan Kebudayaan, 1(1), 97-116. https://doi.org/10.24832/jpnk.v1i1.229

Katz, E. G. (1995). Gender and trade within the household: Observations from rural guatemala. World Development, 23(2), 327-342. https://doi.org/10.1016/0305-750X(94)00118-I

Kementerian Pemberdayaan Perempuan dan Perlindungan Anak Republik Indonesia. (2019). Pembangunan Manusia Berbasis Gender Tahun 2019. https://www.kemenpppa.go.id/lib/uploads/list/44ac0pembangunan-manusia-berbasis-gender-2019.pdf

Lestari, N. I., \& Agusta, I. (2013). Analisis Gender dalam program Simpan Pinjam Untuk Kelompok Perempuan (SPP). Sodality: Jurnal Sosiologi Pedesaan., 1(2), 112-130. https://doi.org/https://doi.org/10.22500/sodality.v1i2.9397

Mardiyaningsih, D. I., Dharmawan, A. H., \& Nasdian, F. (2010). Dinamika sistem penghidupan masyarakat tani tradisional dan modern di Jawa Barat. Sodality: Jurnal Sosiologi Pedesaan, 4(1), 115-145. https://doi.org/10.22500/sodality.v4i1.5850

Meert, H., Van Huylenbroeck, G., Vernimmen, T., Bourgeois, M., \& van Hecke, E. (2005). Farm household survival strategies and diversification on marginal farms. Journal of Rural Studies, 21, 81-97. https://doi.org/10.1016/j.jrurstud.2004.08.007

Pesik, A., Baroleh, J., \& Kaunang, R. (2016). Pola alokasi waktu dan kontribusi pendapatan perempuan pedagang sayuran di Pasar Pinasungkulan Karombasan Manado. Jurnal Agri-SosioEkonomi Unsrat, 12(3), 65-76. https://doi.org/10.35791/agrsosek.12.3.2016.13867

Pradana, H. (2020). Pengembangan pariwisata pasar terapung Kota Banjarmasin. Jurnal Kebijakan Pembangunan, 15(1), 63-76. https://doi.org/10.47441/jkp.v15i1.56

Rahayu, N., \& Darsana, I. (2019). Peran ganda perempuan pedagang cenderamata di objek wisata Tanah Lot Tabanan. E-Jurnal Ekonomi Pembangunan Universitas Udayana, 8(12), 2989-3019. https://ojs.unud.ac.id/index.php/eep/article/view/47717

Salaa, J. (2015). Peran ganda ibu rumah tangga dalam meningkatkan ekonomi keluarga di Desa Tarohan Kecamatan Beo Kabupaten Kepulauan Talaud. Jurnal Holistik Tahun VIII, 15, 1-15. https://ejournal.unsrat.ac.id/index.php/holistik/article/view/7820

Saraswati, Y., \& Dharmawan, A. H. (2015). Resiliensi nafkah rumahtangga petani hutan rakyat di Kecamatan Giriwoyo, Wonogiri. Sodality: Jurnal Sosiologi Pedesaan, 2(1), 63-75. https://doi.org/10.22500/sodality.v2i1.9413

Scoones, I. (1998). Sustainable rural livelihoods: a framework for analysis. IDS Working Paper. https://opendocs.ids.ac.uk/opendocs/handle/20.500.12413/3390

Sopamena, J. F. (2019). Kontribusi perempuan terhadap penerimaan rumah tangga masyarakat Pulau Kecil (studi kasus Kecamatan Teluk Ambon Kota Ambon). Jurnal Ekonomi Pertanian Dan Agribisnis, 3(4), 720-729. https://doi.org/10.21776/ub.jepa.2019.003.04.7

Speranza, C. I., Wiesmann, U., \& Rist, S. (2014). An indicator framework for assessing livelihood resilience in the context of social-ecological dynamics. Global Environmental Change, 28, 109-119. https://doi.org/10.1016/j.gloenvcha.2014.06.005

Sugianti, D. (2017). Strategi pengembangan kawasan wisata pasar terapung berbasis kearifan lokal di Kota Banjarmasin. Jurnal Tata Kelola Seni, 2(2), 20-34. https://doi.org/10.24821/jtks.v2i2.1820

Sugiharto, A., Hartoyo, H., \& Muflikhati, I. (2016). Strategi nafkah dan kesejahteraan keluarga pada 
keluarga petani tadah hujan. Jurnal Ilmu Keluarga Dan Konsumen, 9(1), 33-42. https://doi.org/10.24156/jikk.2016.9.1.33

Susanti, E. (2018). Nilai-nilai kerja keras dan nilai tanggung jawab pada pedagang pasar terapung Kuin Alalak Banjarmasin sebagai sumber belajar IPS. Jurnal Socius : Jurnal Pendidikan Dan Pembelajaran Ilmu Pengetahuan Sosial, 7(2), 241-253. https://doi.org/10.20527/jurnalsocius.v7i2.5425

Widiyanto, Dharmawan, A. H., \& Prasodjo, N. (2010). Strategi nafkah rumahtangga petani tembakau di Lereng Gunung Sumbing: studi kasus di Desa Wonotirto dan Desa Campursari, Kecamatan Bulu, Kabupaten Temanggung. Sodality: Jurnal Sosiologi Pedesaan, 4(1), 91-114. https://doi.org/10.22500/sodality.v4i1.5851

Wijaya, K., \& Kwanda, T. (2019). Galeri "Pasar Terapung" di Banjarmasin. Jurnal EDimensi Arsitektur, II(1), 297-304. http://publication.petra.ac.id/index.php/teknik-arsitektur/article/viewFile/9274/8356

Yulian, B. E., Dharmawan, A. H., Soetarto, E., \& Pacheco, P. (2017). Dilema nafkah rumah tangga pedesaan sekitar perkebunan kelapa sawit di Kalimantan Timur. Sodality :: Jurnal Sosiologi Pedesaan, 5(3), 242-249. https://doi.org/10.22500/sodality.v5i3.19398 